\title{
OBSERVING LIFE IN THE SEA USING ENVIRONMENTAL DNA
}

By Francisco P. Chavez, Markus Min, Kathleen Pitz, Nathan Truelove, Jacoby Baker, Diana LaScala-Grunewald, Marguerite Blum, Kristine Walz,

Charles Nye, Anni Djurhuus, Robert J. Miller, Kelly D. Goodwin, Frank E. Muller-Karger, Henry A. Ruhl, and Christopher A. Scholin

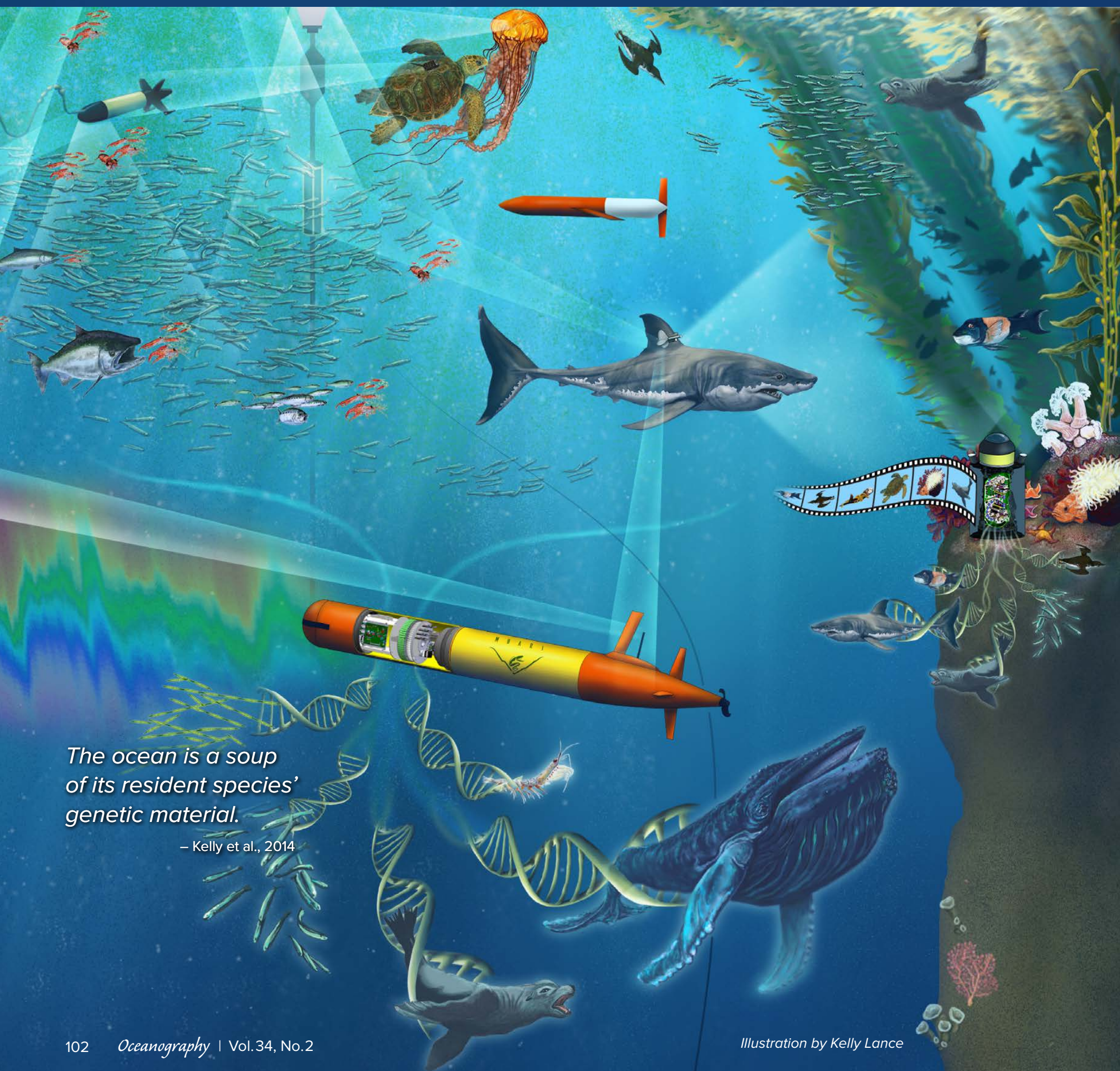


ABSTRACT. The use of environmental DNA (eDNA) for studying the ecology and variability of life in the sea is reviewed here in the context of US interagency Marine Biodiversity Observation Network (MBON) projects. Much of the information in this paper comes from samples collected within US National Marine Sanctuaries. The field of eDNA is relatively new but growing rapidly, and it has the potential to disrupt current paradigms developed on the basis of existing measurement methods. After a general review of the field, we provide specific examples of the type of information that eDNA provides regarding the changing distribution of life in the sea over space (horizontally and vertically) and time. We conclude that eDNA analyses yield results that are similar to those obtained using traditional observation methods, are complementary to them, and because of the breadth of information provided, have the potential to improve conservation and management practices. Moreover, through technology development and standardization of methods, eDNA offers a means to scale biological observations globally to a level similar to those currently made for ocean physics and biogeochemistry. This scaling can ultimately result in a far better understanding of global marine biodiversity and contribute to better management and sustainable use of the world ocean. Improved information management systems that track methods and associated metadata, together with international coordination, will be needed to realize a global eDNA observation network.

\section{INTRODUCTION}

New technologies have revolutionized our understanding of Earth processes. Satellite remote sensing is one of the most well-known technological developments that has transformed our ability to collect information about the temporal and spatial dynamics of Earth's ecosystems. For example, characterization and quantification of the extent of tropical deforestation and changes in land use over time would be difficult, if not impossible, to fully assess without remote sensing. In marine environments, details of the spatial and temporal variations in ocean temperature, sea level, and marine primary productivity have also been greatly advanced using satellite remote sensing. Here we suggest that analysis of environmental DNA (eDNA) from the water column offers a similarly novel perspective that will eventually change paradigms about the structure and dynamics of marine ecosystems.

Remote sensing and eDNA share many attributes: (1) they generate "big data" that are spatially and temporally comprehensive, (2) they require continual reprocessing of data as calibrations are improved and new algorithms or methods are developed, (3) a large number of derived products can be generated from the raw data, and (4) there was early skepticism regarding their potential utility. The thought that we could estimate ocean chlorophyll from space was first proposed half a century ago (Clarke et al., 1970). It was immediately met with doubt: How could we measure such a small signature in reflectance from the ocean surface from space, given the large amount of light scattered and absorbed by gases and aerosols in Earth's atmosphere? Today, after many years of careful work by the marine optics community, we routinely generate reliable daily surface chlorophyll information on a global basis that complements other important Earth observations (Figure 1). Similarly, with eDNA, there is still considerable uncertainty as to how accurately it characterizes the
FIGURE 1. Map showing the locations where samples for this paper were collected and analyzed. The top map is shown over a background of satellite-derived sea surface temperature, the bottom over satellite-derived surface chlorophyll.
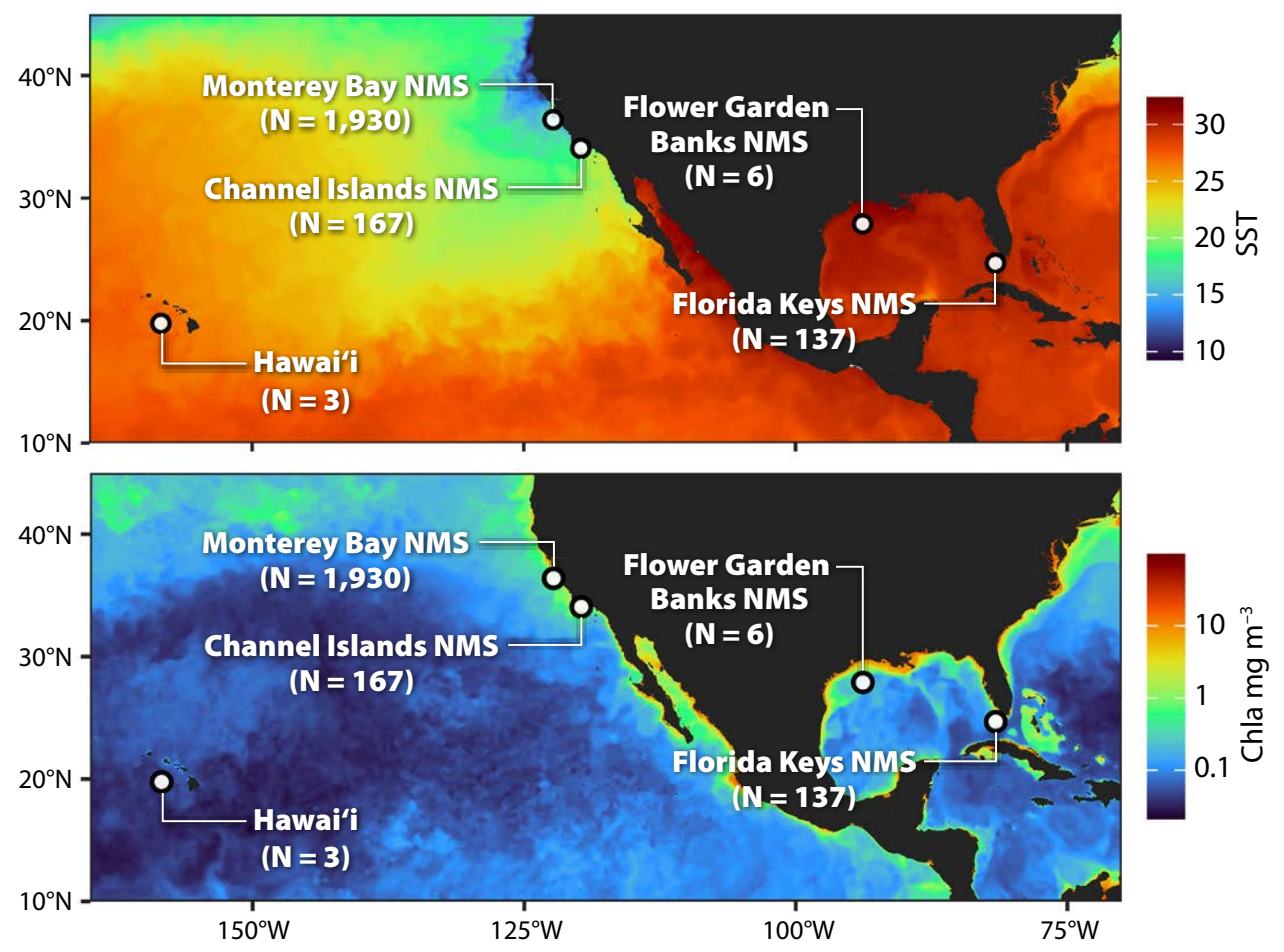
ecological community. In this contribution, we review, at a high level, the progress, utility, and state of the art of eDNA methods for studies of marine biodiversity and ecosystem processes. The results presented are derived primarily from projects funded as demonstration studies for the development of an operational Marine Biodiversity Observation Network (MBON). The information used in this review comes from samples collected mostly within US National Marine Sanctuaries (Figure 1).

\section{WHAT IS MARINE EDNA?}

There has been considerable discussion about what the term "environmental DNA" should encompass (Darling, 2020; Pawlowski et al., 2020; RodriguezEzpeleta et al., 2021). Here, we define marine eDNA as any extractable DNA that is collected by sending a volume of seawater through a filter with small porosity. In the case of smaller organisms (e.g., archaea, bacteria, phytoplankton), the majority of the DNA collected is in the form of living cells or intact organisms (Figure 2). For larger organisms (large zooplankton, fish, marine mammals), DNA can arise from shed tissue, excreta, or other dissolved molecules (Figure 2). This definition is consistent with others that consider "eDNA" to encompass all of the DNA extracted from an environmental sample (Taberlet et al., 2012; Pawlowski et al., 2020; RodriguezEzpeleta et al., 2021).

A variety of methods can be used for analyzing the extracted DNA in order to identify the presence of the full gamut of taxonomic groups representing life in the sea. These methods were first developed in the early 2000s, primarily driven by explorations of microbes in humans (e.g., gut microbiome) and in the surrounding environment (Cristescu and Hebert, 2018). Marine microbiologists were the first in the oceanographic community to be driven to molecular methods in order to: (1) identify and study microbes that, because of their high diversity, the difficulty isolating and culturing them, and their small sizes (less than a micron), made them impossible to characterize using other techniques, and (2) study their metabolic processes using environmental RNA. This methodology transformed the field of marine microbiology (Scholin et al., 2017). The advent of next generation nucleic sequencing in the middle of the first decade of this century accelerated progress in the field (Cristescu and Hebert, 2018). Years later, it was realized that the presence of higher taxa (i.e., vertebrates) could also be detected from eDNA (Thomsen et al., 2012).
Current analytical techniques for eDNA fall into two broad categories: (1) those that target a species directly (e.g., via quantitative polymerase chain reaction, or $\mathrm{qPCR}$, to detect a genetic signature of a specific organism), and (2) those that use metabarcoding to target broad groups of taxa (e.g., bacteria, phytoplankton, invertebrates, vertebrates) (Figure 2). In metabarcoding, short but highly variable portions of a gene (200-400 base pairs) are targeted. The variable target region is located between two highly conserved regions where short segments of eDNA referred to as primers bind and, through PCR, allow the highly variable region to be replicated. The products can then undergo high-throughput sequencing. Following sequencing, bioinformatics software modules are used to quality control the data, identify unique sequences (amplicon sequence variants, ASVs), and then assign taxonomy to the ASVs using information available from genetic databases (see Materials and Methods). The final output for each sample is a list of ASVs detected, their associated taxonomy, and the number of times that the ASV is annotated (number of reads). There is a wide and almost unlimited variety of primers available for use in this workflow; the MBON demonstration projects have focused on four: $16 \mathrm{~S}$ for
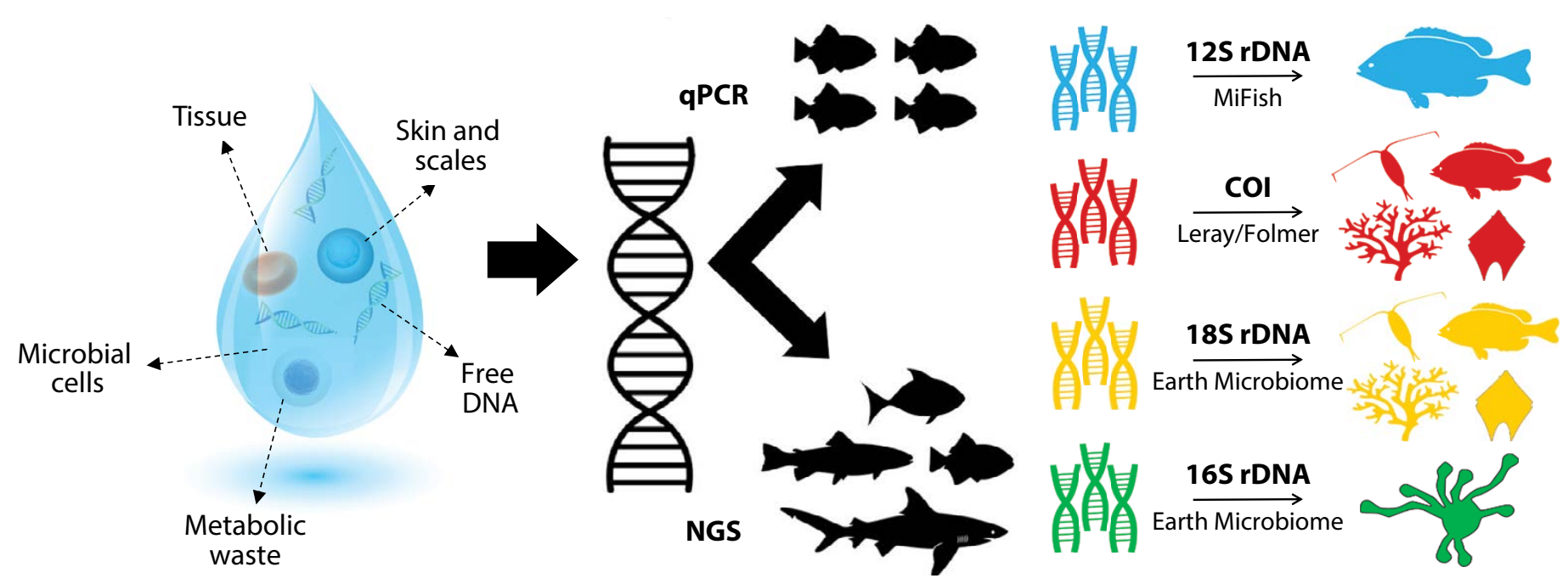

18S rDNA
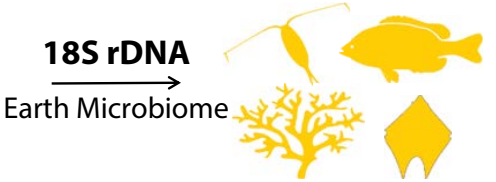

16S rDNA

Earth Microbiome

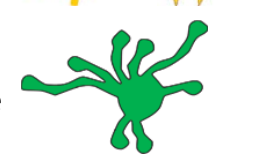

FIGURE 2. Marine eDNA suspended in seawater may contain living cells, metabolic waste, parts of organisms, or dissolved material. As part of the Marine Biodiversity Observation Network (MBON) projects described here, quantitative polymerase chain reaction (qPCR) and metabarcoding have been combined with so-called next generation sequencing. On the right are the primers used by the project with a representation of the range of organisms they detect. More detail can be found in the Materials and Methods section. The eDNA droplet was designed and illustrated by Kevan Yamahara 
microbes (Quince et al., 2011; Parada et al., 2016), $18 \mathrm{~S}$ targeting phytoplankton (Amaral-Zettler et al., 2009), mitochondrial cytochrome-c-oxidase subunit I (COI) targeting invertebrates (Leray et al., 2013; Folmer et al., 1994), and $12 S$ targeting vertebrates (Miya et al., 2015) (Figure 2). In this paper, we limit our analysis and presentation to results from the $18 \mathrm{~S}, \mathrm{COI}$, and $12 \mathrm{~S}$ primers.

\section{THE "eDNA WHEEL"}

Environmental DNA is rapidly becoming an important tool that biologists and oceanographers use to survey marine biodiversity (Figure 3; Bohmann et al., 2014; Thomsen and Willerslev, 2015; Deiner et al., 2017). Figure 4 illustrates an "eDNA wheel" that describes the iterative process of an evolving portfolio of tools and techniques that is catalyzing innovation and driving the field forward. After sample acquisition, the material is processed in the laboratory before it is analyzed locally or sent to a sequencing facility. As noted above, sequencing returns a large data file that undergoes bioinformatic processing, ultimately generating information that is used in the types of assessments described below. It is critical to document metadata associated with each step along this workflow so that information from different programs can be compared, integrated, and synthesized in the context of environmental variables (Box 1).

While data repositories for the raw sequences, driven by the publication process, are available and used routinely (e.g., the International Nucleotide Sequence Database Collaboration; A. Benson et al., 2021, in this issue), repositories for ASVs and associated taxonomic assignments are presently in design and build stages. MBON programs currently have their own data handling systems and analyze the information generated for scientific as well as resource management purposes. The products derived serve to inform new observing campaigns, closing the wheel. Each step of this process evolves and improves over time, eventually leading to a global and operational eDNA monitoring system as a key cornerstone of a comprehensive ecosystem observation network. This effort will accelerate with the recent establishment of an Ocean Biomolecular Observation Network (OBON) in support of the United Nations Ocean Decade for Sustainable Development. In addition to improving eDNA collection, analysis, and information management methods, there is an urgent requirement to enhance the current reference libraries that are used to assign taxonomy to ASVs. The number of "dark taxa"species whose sequences are not in reference librariesis great; a large proportion of the ASVs detected in our samples could not be assigned a taxonomy below the level of kingdom or phylum with certainty.

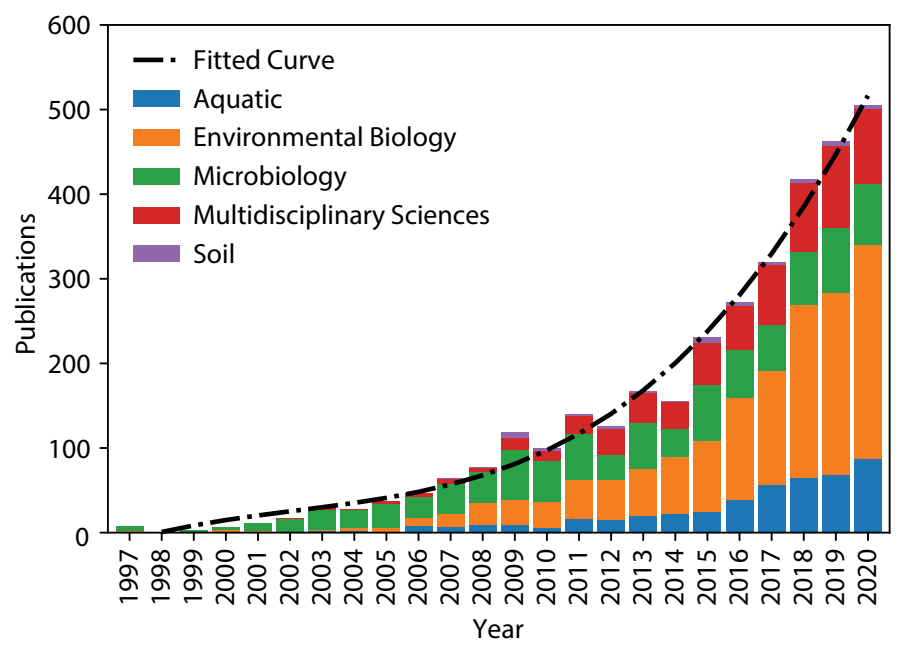

FIGURE 3. Publications from a search of the Web of Science within environmental domains papers using the words "environmental DNA" or "eDNA." Publications have increased exponentially in recent years, demonstrating the growing popularity of this method for marine science and conservation.

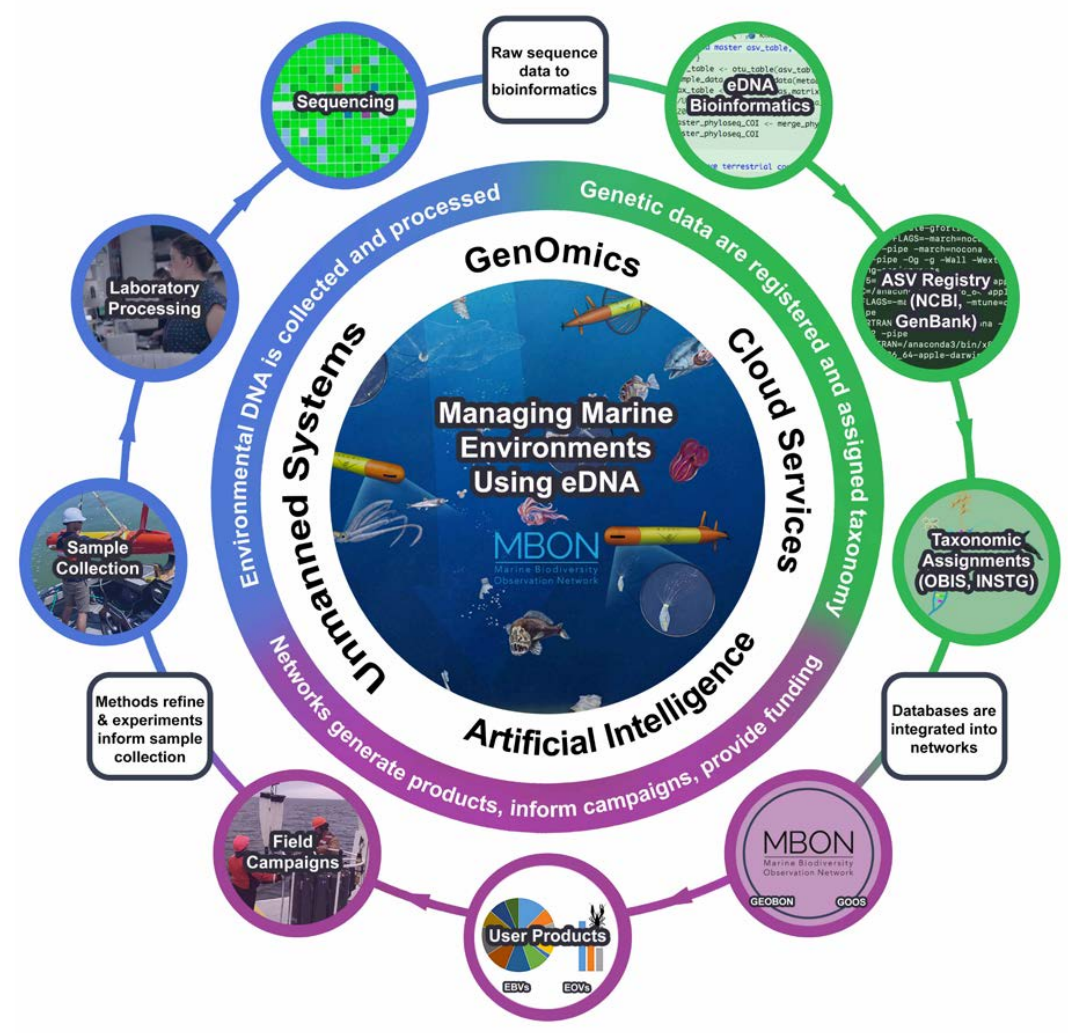

FIGURE 4. The cycle known as the "eDNA wheel" starts with the collection of new samples and moves to processing with evolving laboratory and bioinformatics methods, then feeding of databases that are analyzed to develop products to be used for scientific, management, and conservation purposes. The information gleaned aids in generating new and improved field sampling campaigns that in turn stimulate further innovations in techniques used in the laboratory, in the bioinformatics pipeline, and in data management and product generation systems. With each cycle, every aspect of the eDNA workflow becomes more efficient and standardized, providing a framework for global coordination and participation. 


\section{BOX 1. From Local Observations to Clobal Conclusions: The Path to Integrate Local eDNA Data into Clobal Biodiversity Studies}

THE IMPORTANCE OF CONTEXTUAL DATA. Environmental DNA (eDNA) offers a snapshot of organisms within an environment, but many environmental factors influence how much information a single eDNA sample can reveal about a local biological community. By collecting data about the environment and delineating methods used to collect, process, and analyze an eDNA sample, we can increase our ability to interpret results and place them within the global context of how life is changing in the ocean.

\section{DOCUMENTATION INCREASES REPRODUCIBILITY AND REUSE} OF DATA AND SAMPLES. Data interoperability or the ability for data to be exchanged and used by multiple institutions is a huge challenge for the rapidly evolving field of environmental DNA. Knowledge of the methods used to collect, process, and analyze an eDNA sample are critical for interpretation of the data, and it affects our ability to compare data sets. Results can depend on all of the methods used along the eDNA workflow (Figure B-1) from sample collection (e.g., filter type and size, filtering method, preservation method) to wet lab procedures (e.g., extraction, polymerase chain reaction $[P C R]$ ), and finally to computational analyses (e.g., OTU/ASV clustering or denoising method, taxonomic annotation) (Pitz et al., 2020; Zaiko et al., 2021). Documentation of the methods, reagents, tools, and techniques at each stage of this pipeline allows for a broader interpretation of results. Such documentation also opens the door for local data sets to be combined regionally and globally once the effects of some of these methodological differences are better understood (see A. Benson et al., 2021, in this issue). Tools are being developed to better share and document detailed omic protocols through the Ocean Best Practices System (Samuel et al.,
2021). These protocols could then be linked to eDNA data in global biodiversity repositories, such as the Ocean Biodiversity Information System (OBIS), to make eDNA data broadly available in the future. Using the Global Biodiversity Information System's (GBIF) new guide to publishing DNA-derived biodiversity data (Andersson et al., 2020), we were able to convert a subset of our eDNA data into Darwin Core Standard format (Wieczorek et al., 2012) and submit it to OBIS and GBIF (Chavez and Pitz, 2021; Chavez et al., 2021), where it can complement global biodiversity data from other sources.

COLLECTION FOR FUTURE USE. One of the major advantages of eDNA in relation to other biological observation methods is its ability to detect many different sizes and classes of organisms from the same sample of water. In addition, an archived eDNA sample can be interrogated in the future with improved methods or to target a different group of organisms. Preserving environmental samples alongside their collecting/processing methods expands the ability of the eDNA community to take advantage of archived samples, affording us the ability to "go back in time." In a rapidly changing world, where many environments and ecosystems are being dramatically altered, collecting samples now with an eye to future use may help us disentangle the natural from human-impacted states of many ecosystems. Within the MBON project, we have worked to combine eDNA data sets from different local sampling efforts in order to examine regional patterns in biodiversity. As more local efforts are combined across projects, our ability to make global conclusions about trends in biodiversity based on eDNA data depends significantly on the quality of our documentation.

Local eDNA Metabarcoding Project Pipeline

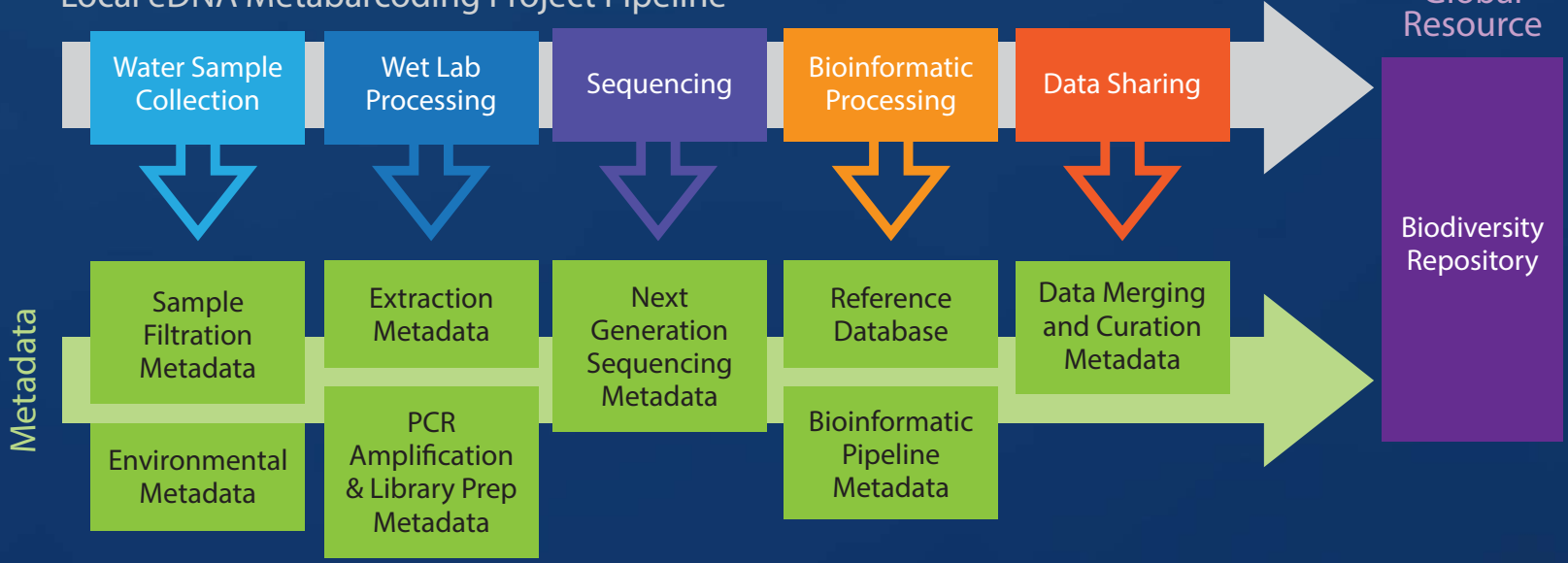

FICURE B-1. For information from different laboratories/countries to be integrated for large-scale analysis, metadata must be rigorously assembled along the eDNA workflow from sample collection to laboratory processing to bioinformatics to storage. 
FIGURE 5. Vertical distribution of suspended DNA and particulate nitrogen concentrations from samples collected in the Monterey Bay region. The profiles were created taking all of the available data for the region and are not from overlapping periods. The two profiles are very similar and highly correlated with each other.

\section{THE GENERAL DISTRIBUTION OF EDNA CONCENTRATION IN THE MARINE ENVIRONMENT}

The concentration of suspended DNA in the marine environment closely follows the concentration of small planktonic organisms in surface waters (Figures 5 and 6a). In the sunlit surface, where phytoplankton grow and reproduce, total suspended DNA is highest. The vertical profile of DNA concentration closely matches that of particulate nitrogen (as well as carbon and chlorophyll, not shown). At depth, particulate nitrogen (and DNA) is mostly found in sinking surface material and non-photosynthetic microbes (archaea and bacteria) (Arnosti et al., 2019). A similar pattern can be observed in surface waters that extend from the nearshore nutrient-rich California coastal upwelling environment to the less productive waters of the California Current and beyond (Figure 6a; see also Figure 1 for spatial patterns). The "non-living" suspended DNA is found in much lower concentrations, requiring targeted amplification for detection. In some cases, the higher taxa eukaryotic component of eDNA was found to be less than 1\% (Stat et al., 2017). In coastal surface waters, phytoplankton comprise the majority of eDNA, and that from vertebrates is often $<0.01 \%$ of the total. While metabarcoding primers target specific taxonomic groups, they can also amplify off-target regions and species. Vertebrate primers are particularly susceptible to off-target microbial amplification that can overwhelm the signature of the targeted vertebrate groups. Removal of these microbial products before sequencing is required to enhance the quality of vertebrate assays (West et al., 2021).

FIGURE 6. Environmental DNA distributions during the spring upwelling period sampled along California Cooperative Oceanic Fisheries Investigations (CalCOFI) Line 67 from Monterey Bay to $300 \mathrm{~km}$ offshore. Panel (a) shows the relationship between extracted DNA concentration and chlorophyll. Panel (b) shows the relationship between phytoplankton biomass estimated from microscopic counts and eDNA reads for diatoms; both follow an expected pattern similar to chlorophyll, given that diatoms are the primary bloom formers under upwelling conditions (Chavez et al., 2017). Panel (c) shows the distribution in the number of copepod reads, low nearshore, and higher offshore. This pattern is characteristic for the Central California region (Messié and Chavez, 2017). The average distribution of zooplankton as sampled by the CalCOFI program using net tows is also included. Panel (d) charts the transition from a nearshore $(<100 \mathrm{~km})$ anchovy (Engraulis mordax) dominated region to an offshore one dominated by the oceanic jack mackerel (Trachurus symmetricus), all from near-surface samples.
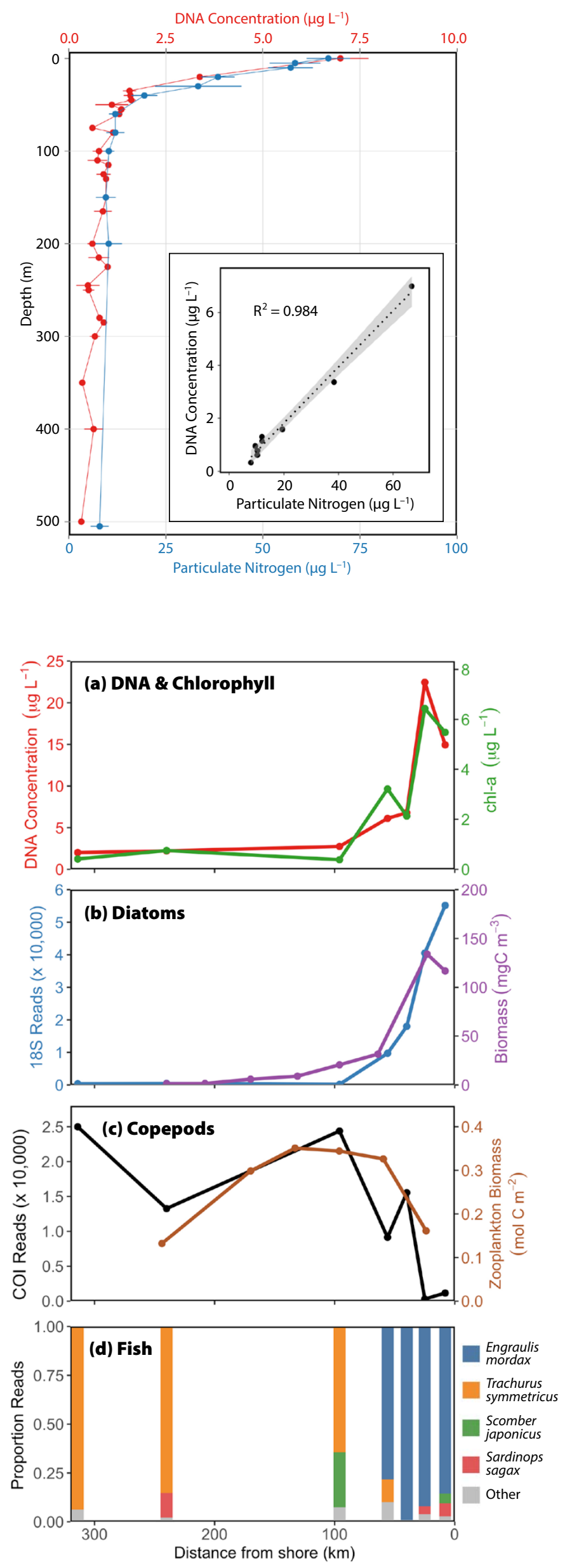


\section{THE USE OF EDNA IN STUDIES OF SPATIAL DISTRIBUTION}

The information used in this paper comes mostly from sample collections made in US National Marine Sanctuaries (NMSs). The bulk of the data is from samples collected in the Monterey Bay NMS, although samples from the Florida Keys, Channel Island, and Flower Garden Banks NMSs were also included (Figure 1) and used in this comparative analysis. The large and complex data sets generated by eDNA metabarcoding techniques can be reduced by using principal component analysis (PCA). PCA condenses the variability of a data set into fewer dimensions that can then be examined through new, uncorrelated variables, or principal components (PCs), simplifying interpretation with minimal information loss. Because DNA sequence data are considered inherently compositional, "robust" variants of PCA have been developed that account for compositionality and sparsity (i.e., the high number of non-detections or " 0 "s in the data set). Here, we use the Robust Aitchison PCA (RPCA) method developed within the Qiime2 computational ecosystem called DEICODE, which uses Aitchison distance, a compositional distance metric, as well as a form of matrix completion that accounts for high levels of sparsity (Martino et al., 2019). PCA results can be visualized by plotting samples by their PC scores and interpreting clustering patterns using sample metadata. The underlying influence of different taxa on a sample's PC score can also be examined through "loading scores," which is the weight of each ASV towards calculating the overall PC score. In this manner, we are able to examine how samples across a data set are similar or dissimilar across a few dimensions, and we can pick out the taxa most responsible for this variability.

When samples are compared across different environments from four different NMSs, samples from cooler and more productive coastal upwelling regions of the US West Coast cluster together (e.g., Channel Islands and Monterey Bay), as do samples from the warmer, more stratified regions of the Gulf of Mexico (e.g., Florida Keys and Flower Garden Banks; Figure 7a,c COI and $18 \mathrm{~S}$ data sets, respectively). Samples also clustered seasonally within these groups, with samples taken during summer or winter months segregating as highlighted in Figure 7b (COI) and 7d (18S). Across this large data set, patterns of diversity in the unique sequences (ASVs) that were assigned to the same species were also observed. For example, ASVs associated with the abundant haptophyte Emiliana huxleyi display differences in sequence diversity between the upwelling and tropical NMSs (Figure 7e). Large differences in overall community composition across samples
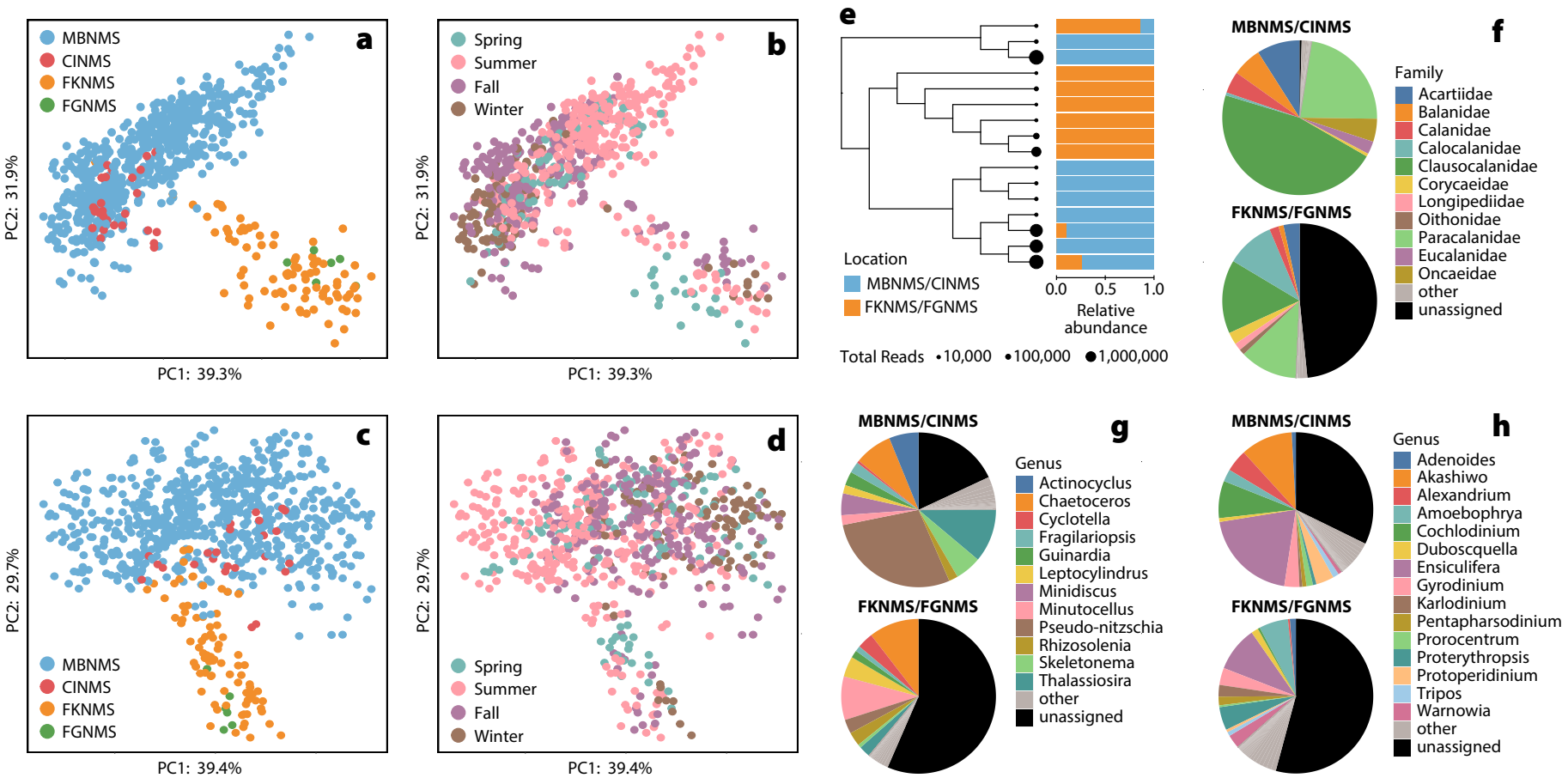

FIGURE 7. Comparison of samples collected within four US National Marine Sanctuaries; Monterey Bay (MBNMS), Florida Keys (FKNMS), Channel Islands (CINMS), and Flower Garden Banks (FGNMS). Robust Aitchison principal component analysis (RPCA) of surface samples (0-20 m) using mitochondrial cytochrome-c-oxidase subunit I (COI) ( $a$ and b) and 18S (c and d) data, showing location (a and c) and seasonality (b and d). (e) Phylogenetic tree and relative abundance information for COI Emiliania huxleyi amplicon sequence variants (ASVs) that were the 10 most abundant E. huxleyi ASVs for either MBNMS and CINMS (blue) or FKNMS and FGNMS (orange). (f) Pie charts showing the relative abundance of different Hexanauplia families detected via COI. (g) Pie charts showing the relative abundance of diatom genera detected via $18 \mathrm{~S}$. (h) Pie charts showing the relative abundance of dinoflagellate genera detected with 18S. Note the large number of ASVs not assigned to either genus or family. 
from these different regions were also found: Figure $7 f-h$ shows the relative proportions of Hexanauplii (mostly copepods, COI), diatoms (18S), and dinoflagellates (18S) from the upwelling and lower-latitude regions. The black proportion of Figure $7 \mathrm{f}-\mathrm{h}$ represents the ASVs that have not been assigned to the targeted taxonomic level (genus or family) because there are no closely matching DNA sequences in current genetic repositories. This result highlights the need to improve current genetic libraries, because at times over $50 \%$ of the ASVs remained unassigned. Interestingly, a higher proportion of unassigned ASVs are observed in the warmer, lowerlatitude regions. These high biodiversity, lower biomass regions appear less represented in genetic repositories. In cooler, lower diversity upwelling regions like those of the West Coast, higher biodiversity is not necessarily a favorable state for that ecosystem. For example, an increase in biodiversity in zooplankton (copepods) is often associated with decreased productivity during warm El Niño years as more nutritious coldwater species are replaced by numerous warm-water-adapted species (Peterson and Keister, 2003).
A similar RPCA analysis for vertebrates (12S) failed to pick up the same patterns as the other primers. This was likely the result of the fact that there are few overlapping vertebrate species/ ASVs between the cool and warm NMSs (Figure 8). While RPCA has an increased ability to handle sparse data sets, it can still produce a misleading ordination when there is little to no compositional overlap between samples (Martino et al., 2019; Figure 8 and Table 1). Instead, to visualize community-level differences between seawater samples taken in the four test regions (Monterey Bay, Channel Islands, Florida Keys, and Flower Garden Banks), we performed non-metric multidimensional scaling (NMDS) using the $\mathrm{R}$ package vegan (Oksanen et al., 2019; Figure 8). NMDS is an iterative algorithm that attempts to accurately represent the dissimilarity between each pair of samples in n-dimensional space; samples in the resulting plot are more dissimilar if they are farther apart (Buttigieg and Ramette, 2015). Before running NMDS, samples were rarefied to 2,000 observations per sample. The dissimilarity between each pair of samples was then calculated using Bray-Curtis Dissimilarity (Bray and Curtis, 1957), a common choice in community ecology that takes into account both the presence and abundance of different species/ASVs in comparing samples. NMDS was able to represent the community composition of our water samples (Figure 8b). As with the RPCA results for the $18 \mathrm{~S}$ and COI data sets, a visual assessment of the plot indicates that water samples can be separated into two groups, one for Monterey Bay and Channel Islands, and one for Florida Keys and Flower Garden Banks. This result suggests that water samples in the first group are compositionally more similar to each other than water samples in the second group.

Finer-scale spatial variations are evident from onshore-offshore transects in the Monterey Bay NMS (Figure 6). This region is characterized by winddriven coastal upwelling that occurs within the first $25-30 \mathrm{~km}$ from the coast and brings deeper, nutrient-rich water to the well-lit surface, where it stimulates phytoplankton photosynthesis and growth. Chlorophyll, a signature of phytoplankton concentration and suspended DNA, is higher nearshore and decreases going offshore as nutrients are consumed (Figure 6a). The dominant phytoplankton in upwelling regions such as

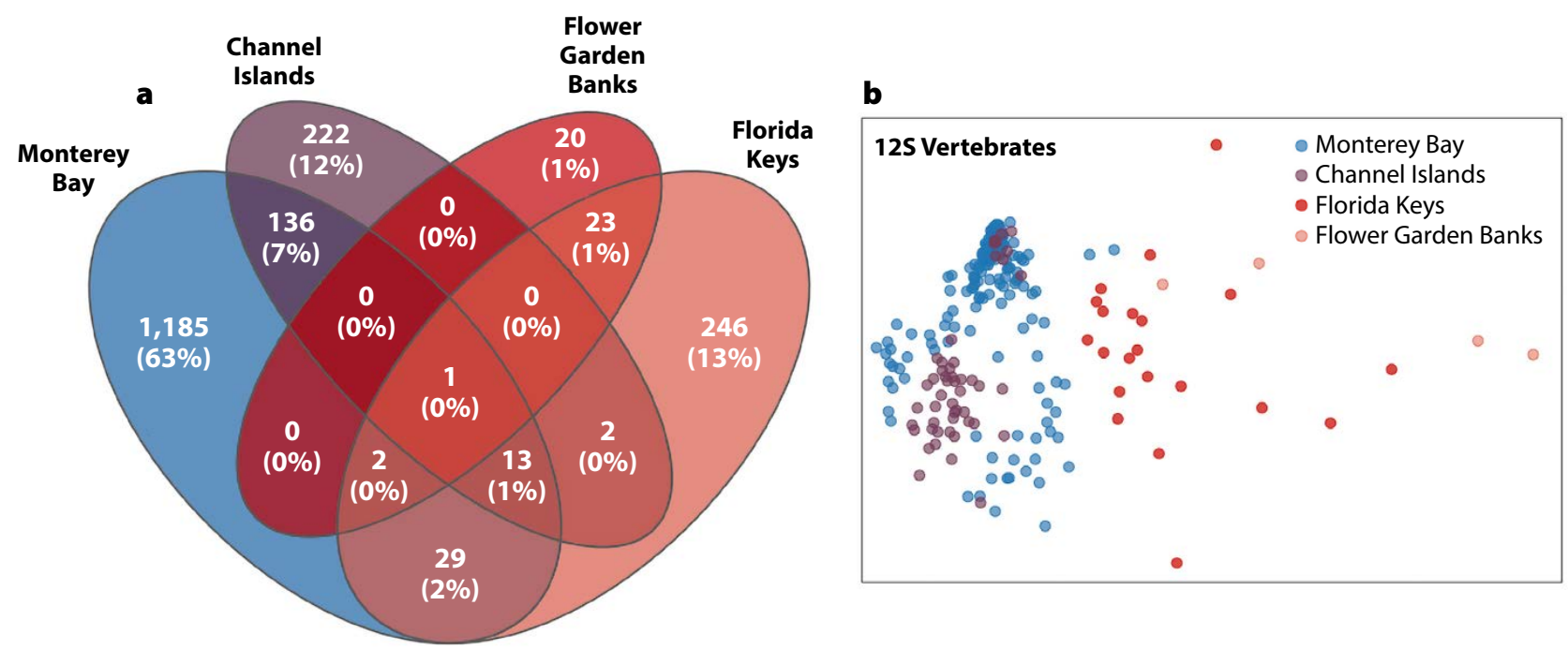

FIGURE 8. (a) A Venn diagram of the overlap in $12 \mathrm{~S}$ vertebrate ASVs from all four NMS (Monterey Bay, Channel Islands, Florida Keys, and Flower Garden Banks). The percentage of overlapping ASVs in the Monterey Bay and Channel Islands samples (8\%) and in the Florida Keys and Flower Garden Banks samples (26\%) is greater than the percentage of overlapping ASVs in any of the other pairwise combinations of regions (0\%-3\%). (b) The outcome of a non-metric multidimensional scaling (NMDS) analysis of the same data set (stress $=0.16$ ). The plot indicates that water samples cluster into two groups, one for Monterey Bay and Channel Islands, and one for Florida Keys and Flower Garden Banks. 


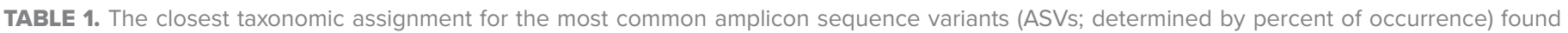

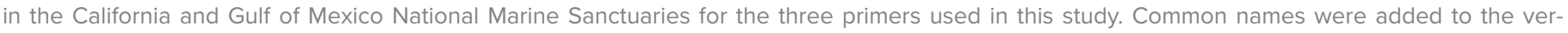
tebrate (12S) results.

\begin{tabular}{|c|c|c|c|c|c|}
\hline $\begin{array}{l}\text { Engraulis mordax } \\
\text { Northern anchovy }\end{array}$ & Family Clupeidae & Phylum Picozoa & Class Onmycetes & Ensiculifera imariensis & Ensiculifera imariensis \\
\hline Northern anchovy & $\begin{array}{l}\text { Engraulis eurystole } \\
\text { Silver anchovy }\end{array}$ & Emiliania huxleyi & Family Saprolegniaceae & Class Dinophyceae & $\begin{array}{l}\text { Dinophyceae sp. } \\
\text { CCMP1878 }\end{array}$ \\
\hline $\begin{array}{l}\text { Sardinops sagax } \\
\text { Pacific sardine }\end{array}$ & $\begin{array}{l}\text { Genus Lutjanus } \\
\text { Snapper }\end{array}$ & Emiliania huxleyi & Phylum Picozoa & Class Spirotrichea & Class Dinophycea \\
\hline Northern anchovy & $\begin{array}{l}\text { Family Haemulidae } \\
\text { Grunts }\end{array}$ & Bathycoccus prasinos & Kingdom Eukaryota & Order Peridiniales & Kingdom Eukaryota \\
\hline Pacific sardine & $\begin{array}{l}\text { Gobiosoma ginsburgi } \\
\text { Seaboard goby }\end{array}$ & Emiliania huxleyi & Emiliania huxleyi & Kingdom Eukaryota & Kingdom Eukaryota \\
\hline Northern anchovy & $\begin{array}{l}\text { Genus Hemiramphus } \\
\text { Halfbeaks, garfish, or ballyhoos }\end{array}$ & Phylum Picozoa & Emiliania huxleyi & Genus Phaeocystis & Class Dinophycea \\
\hline Northern anchovy & $\begin{array}{l}\text { Genus Myrophis } \\
\text { Eels }\end{array}$ & Phaeocystis globosa & Kingdom Eukaryota & Genus Thalassiosira & Kingdom Eukaryota \\
\hline Northern anchovy & $\begin{array}{l}\text { Lagodon rhomboides } \\
\text { Pinfish }\end{array}$ & Family Sargassace & Family Clionaidae & Class Dinophyceae & Class Dinophycea \\
\hline Pacific sardine & $\begin{array}{l}\text { Genus Myrophis } \\
\text { Eels }\end{array}$ & Phaeocystis globosa & Class Onmycetes & $\begin{array}{l}\text { Dinophyceae sp. } \\
\text { UDMS0803 }\end{array}$ & Class Dinophycea \\
\hline $\begin{array}{l}\text { Family Atherinopsidae } \\
\text { Silversides }\end{array}$ & $\begin{array}{l}\text { Family Gobiidae } \\
\text { True gobies }\end{array}$ & Bathycoccus prasinos & Emiliania huxleyi & Phylum Cryptophyta & Family Bacillariaceae \\
\hline Northern anchovy & $\begin{array}{l}\text { Family Haemulidae } \\
\text { Grunts }\end{array}$ & Emiliania huxleyi & $\begin{array}{l}\text { Family } \\
\text { Chrysochromulinaceae }\end{array}$ & Kingdom Eukaryota & Kingdom Eukaryota \\
\hline $\begin{array}{l}\text { Citharichthys sordidus } \\
\text { Pacific sanddab }\end{array}$ & $\begin{array}{l}\text { Family Gerreidae } \\
\text { Mojarras }\end{array}$ & $\begin{array}{l}\text { Family } \\
\text { Chrysochromulinaceae }\end{array}$ & Kingdom Eukaryota & $\begin{array}{l}\text { Dinophyceae sp. } \\
\text { CCMP1878 }\end{array}$ & Adenoides eludens \\
\hline $\begin{array}{l}\text { Trachurus symmetricus } \\
\text { Pacific jack mackerel }\end{array}$ & $\begin{array}{l}\text { Bothus robinsi } \\
\text { Twispot flounder }\end{array}$ & Family Triparmaceae & Kingdom Eukaryota & Genus Paracalanus & Kingdom Eukaryota \\
\hline Northern anchovy & $\begin{array}{l}\text { Genus Caranx } \\
\text { Jacks }\end{array}$ & $\begin{array}{l}\text { Family } \\
\text { Chrysochromulinaceae }\end{array}$ & Ascidia ahodori & $\begin{array}{l}\text { Family } \\
\text { Thalassiosiraceae }\end{array}$ & Phylum Cryptophyta \\
\hline $\begin{array}{l}\text { Genus Scomber } \\
\text { Mackerel }\end{array}$ & $\begin{array}{l}\text { Family Haemulidae } \\
\text { Grunts }\end{array}$ & Class Phaeophyceae & $\begin{array}{l}\text { Family } \\
\text { Chrysochromulinaceae }\end{array}$ & Adenoides eludens & Kingdom Eukaryota \\
\hline Northern anchovy & $\begin{array}{l}\text { Clepticus parrae } \\
\text { Creole wrasse }\end{array}$ & $\begin{array}{l}\text { Family } \\
\text { Chrysochromulinaceae }\end{array}$ & Kingdom Eukaryota & Lepidodinium viride & Order Prymnesiales \\
\hline Northern anchovy & $\begin{array}{l}\text { Family Engraulidae } \\
\text { Anchovies }\end{array}$ & $\begin{array}{l}\text { Family } \\
\text { Chrysochromulinaceae }\end{array}$ & Family Aglaopheniidae & Order Prymnesiales & Lepidodinium viride \\
\hline Northern anchovy & $\begin{array}{l}\text { Family Monacanthidae } \\
\text { Filefish }\end{array}$ & Bathycoccus prasinos & Class Oomycetes & Family Strombidiidae & Phylum Chlorophyta \\
\hline Northern anchovy & Class Actinopteri & $\begin{array}{l}\text { Family } \\
\text { Chrysochromulinaceae }\end{array}$ & Class Mediophyceae & Kingdom Eukaryota & $\begin{array}{l}\text { Family } \\
\text { Heterocapsaceae }\end{array}$ \\
\hline $\begin{array}{l}\text { Merluccius productus } \\
\text { Pacific hake }\end{array}$ & $\begin{array}{l}\text { Family Gobiidae } \\
\text { True gobies }\end{array}$ & $\begin{array}{l}\text { Paracalanus sp. } \\
\text { C AC-2013 }\end{array}$ & Family Paulinellidae & Actinocyclus curvatulus & Genus Karlodinium \\
\hline $\begin{array}{l}\text { Genus Sebastes } \\
\text { Rockfish }\end{array}$ & $\begin{array}{l}\text { Genus Canthidermis } \\
\text { Triggerfish }\end{array}$ & $\begin{array}{l}\text { Family } \\
\text { Skeletonemataceae }\end{array}$ & $\begin{array}{l}\text { Family } \\
\text { Chrysochromulinaceae }\end{array}$ & Phylum Chlorophyta & Family Bacillariaceae \\
\hline Northern anchovy & $\begin{array}{l}\text { Genus Acanthurus } \\
\text { Surgeonfish }\end{array}$ & Kingdom Eukaryota & Kingdom Eukaryota & Kingdom Eukaryota & Class Dinophycea \\
\hline $\begin{array}{l}\text { Leuroglossus schmidti } \\
\text { Northern smoothtongue }\end{array}$ & $\begin{array}{l}\text { Genus Lutjanus } \\
\text { Snapper }\end{array}$ & Kingdom Eukaryota & Kingdom Eukaryota & $\begin{array}{l}\text { Genus } \\
\text { Pentapharsodinium }\end{array}$ & $\begin{array}{l}\text { Chrysochromulina sp. } \\
\text { NIES-1333 }\end{array}$ \\
\hline Northern anchovy & $\begin{array}{l}\text { Lutjanus griseus } \\
\text { Gray snapper }\end{array}$ & $\begin{array}{l}\text { Paracalanus sp. } \\
\text { C AC-2013 }\end{array}$ & $\begin{array}{l}\text { Family } \\
\text { Chrysochromulinaceae }\end{array}$ & Genus Warnowia & Gyrodinium jinhaense \\
\hline $\begin{array}{l}\text { Stenobrachius } \\
\text { leucopsarus } \\
\text { Northern lampfish }\end{array}$ & $\begin{array}{l}\text { Family Sparidae } \\
\text { Seabreams, porgies }\end{array}$ & Phylum Picozoa & Kingdom Eukaryota & Oithona similis & Genus Oikopleura \\
\hline Northern anchovy & $\begin{array}{l}\text { Family Serranidae } \\
\text { e.g., sea basses and groupers }\end{array}$ & $\begin{array}{l}\text { Aureococcus } \\
\text { anophagefferens }\end{array}$ & Kingdom Eukaryota & Genus micromonas & Lepidodinium viride \\
\hline $\begin{array}{l}\text { Genyonemus lineatus } \\
\text { White croacker }\end{array}$ & $\begin{array}{l}\text { Family Sparidae } \\
\text { Seabreams, porgies }\end{array}$ & Phylum Picozoa & Family Chromulinaceae & Ensiculifera imariensis & Order Gymnodiniales \\
\hline Northern anchovy & Class Actinopteri & Kingdom Eukaryota & Ascidia ahodori & Rhizosolenia setigera & $\begin{array}{l}\text { Theleodinium } \\
\text { calcisporum }\end{array}$ \\
\hline $\begin{array}{l}\text { Peprilus medius } \\
\text { Pacific harvestfish }\end{array}$ & $\begin{array}{l}\text { Mulloidichthys vanicolensis } \\
\text { Yellowfin goatfish }\end{array}$ & Phylum Bacillariophyta & Clausocalanus furcatus & Ensiculifera imariensis & $\begin{array}{l}\text { Warnowia sp. } \\
\text { BSL-2009a }\end{array}$ \\
\hline
\end{tabular}


Monterey Bay are diatoms (Margalef, 1978; Chavez et al., 2017). Not surprisingly, diatom distribution (as measured by both microscopic counts and by eDNA metabarcoding) shows a pattern very similar to chlorophyll concentration (Figure 6b). The observed pattern for phytoplankton grazers like copepods and euphausiids from net tows taken by the California Cooperative Oceanic Fisheries Investigations (CalCOFI) program shows a broad maximum at the outer edge of the upwelling zone (Messié and Chavez, 2017); this pattern is also captured with eDNA metabarcoding (Figure 6c). The relative distribution of fish species from eDNA along this same transect also follow expected patterns, with the northern anchovy dominating in the nearshore upwelling region and the more oceanic jack mackerel dominating in the offshore regions (Figure 6d).

\section{THE INFLUENCE OF DEPTH ON COMMUNITY STRUCTURE}

The Monterey Bay and California Current regions have a rich history of eDNA studies, beginning with the seminal paper by Kelly et al. (2014) that describes analysis of bay waters from the Monterey Bay Aquarium open ocean tank containing vertebrate species from the region. Subsequently, there have been studies of kelp bed vertebrate communities in central (Port et al., 2016) and southern (Lamy et al., 2021) California. Several eDNA efforts regarding fisheries surveys are ongoing, including the central California Rockfish Recruitment and Ecosystem Assessment Surveys (Closek et al., 2019). More recently, Djurhuus et al. (2020) analyzed seasonal data from MBARI's C1 time-series station to identify relations across broad taxonomic groups in waters at the at the mouth of the Monterey Bay submarine canyon.

In this section, we explore changes in communities and individual groups or species with depth as gleaned from eDNA analysis of samples collected in the Monterey Bay NMS. Within both $18 \mathrm{~S}$ and COI data sets, Shannon diversity and ASV richness are lowest at the surface, with these samples dominated by a smaller number of ASVs (Figure 9). Waters below the euphotic zone (50 $\mathrm{m}$ in Monterey Bay) show higher and similar diversity down to $700 \mathrm{~m}$. Samples taken below the euphotic zone were also compositionally more similar to each other than to surface samples. This is likely the result of environmental conditions being relatively uniform below the thermocline; the drivers of the general composition of deep communities are expected to be similar globally (i.e., adaptations to temperature, pressure, food availability). For example, a comparison of COI data from Hawai' $i$ and Monterey Bay (not shown) indicates that the deep commu- nities from these distant sites are more similar to each other than they are to their respective surface communities. The vertical patterns for $12 \mathrm{~S}$, however, are different, with a more uniform distribution of Shannon diversity with depth and less discrimination between depths by community composition. This eDNA homogenization with depth could be driven by: (1) fish and mammals, which are known to vertically migrate over relatively large distances, (2) fish and mammal fecal material, which is heavier and will sink faster with less degradation than the sinking material of smaller phytoplankton and zooplankton, or (3) vertebrate communities, which are less diverse so differences in depth are less detectable by these methods.

The vertical distribution of key taxa as assessed from eDNA shows patterns that are expected from what is known about their ecology and distribution in Monterey Bay (Figure 10). Diatoms are mostly photosynthetic organisms that dominate surface populations in upwelling regions; their vertical eDNA-read profiles show a surface maximum and a decreasing trend with depth closely matching the mean profile of dissolved oxygen for the region (Figure 10a). The significant number of reads at depth confirms that these organisms are important contributors to the vertical flux of material to the deep sea. The Hexanauplii (a) 185

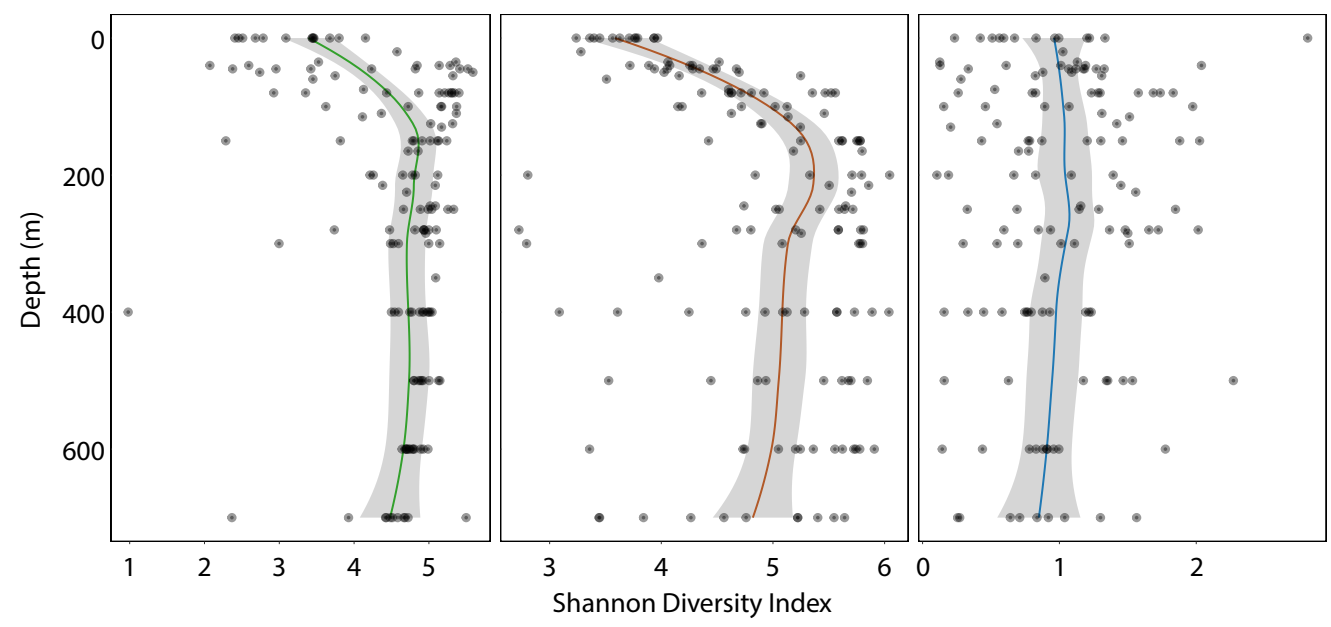

FIGURE 9. Changes in biodiversity with depth for the three primers used in this paper. Shannon diversity values are plotted for each sample at each depth. A line was fit to the data using the loess method for local regression with the standard error represented by the shaded regions. Within the $18 \mathrm{~S}$ (a) and COI (b) data sets, lower diversity at the surface is observed, reaching a maximum value around $150 \mathrm{~m}$ and remaining similar through the rest of the water column. Within the $12 \mathrm{~S}$ (c) data set, a-diversity remains similar from surface to depth. Shannon diversity values were calculated from data rarefied to a depth of 2,000 observations per sample. The patterns with or without rarefaction are similar. 
(mostly copepods), known to graze on phytoplankton (Suzuki et al., 1999), show a similar surface enhancement but with a maximum just below that of diatoms (Figure 10b). This pattern has been observed using other techniques and explained as a strategy to feed where sinking material from the euphotic zone is highest while at the same time remaining in a low-light predation environment (Jackson and Checkley, 2011). The same pattern of surface enhancement observed for diatoms is also seen for the northern anchovy (Engraulis mordax; Figure 10c), a well-known surface dweller that grazes on diatoms and zooplankton (Ryther, 1969; Espinoza and Bertrand, 2008). We have found anchovy eDNA to be prevalent throughout the water column and measured it to depths of $3,000 \mathrm{~m}$. This indicates an unappreciated role of this species in providing nutrition to midwater and benthic communities as well as export of carbon to the deep sea. Two well-known deeper dwelling organisms, Pacific hake and a species of myctophid, show clear eDNA maxima at depth
(Figure 10d,e). The vertical distribution of eDNA from these two organisms can be influenced by their extensive diel vertical migrations. The vertical distribution of a common Monterey Bay jellyfish (Aegina sp.) as measured over several decades by video from a remotely operated vehicle (ROV) has also been compared with the number of eDNA reads (Figure 11). The data are highly correlated, with the less dense (a few profiles) eDNA measurements being noisier.

\section{UTILIZING EDNA TO DETECT CHANGE OVER TIME}

The MBON projects began collecting targeted eDNA samples in 2015. Samples collected and preserved for other purposes prior to that date allowed us to develop time series and evaluate changes going back further in time. This sample archeology was motivated by large changes in climate, reflected in sea surface temperature records and changes in the distributions of fish and marine mammals. We noted the appearance of large numbers of whales close to shore and near the MBARI laboratory facilities in 2014-2015, around the time the project started. This appearance was associated with a significant marine heatwave that affected the Northeast Pacific and Monterey Bay (Bond et al., 2015; Chavez et al., 2017). This large-scale marine heatwave was nicknamed "the blob" and was associated with an intense episode of a mode of climate variability known as the North Pacific Gyre Oscillation. A large El Niño immediately followed the blob in 2015/2016 (Chavez et al., 2017). These two climatic phenomena reduced primary productivity for the region overall, leading to a decrease in the size of the productive habitat to a very narrow region nearshore, a process referred to as habitat compression. These climatic disturbances and the associated compression led to a series of ecological consequences, including the entanglement of whales with nearshore crab pots (Santora et al., 2020). Surveys of the region found

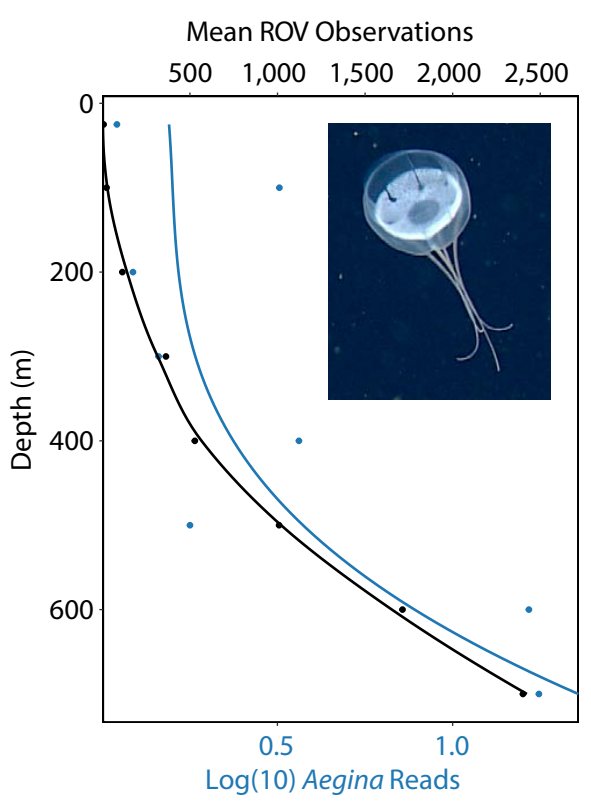

FIGURE 11. Mean vertical profile of Aegina sp. (jellyfish) over the past several decades in Monterey Bay as estimated from video collected during remotely operated vehicle (ROV) dives (in black) compared with a mean profile from a much smaller number of vertical profiles of eDNA reads (in blue). Lines were fitted to the data using the loess method for local regression for the ROV data and a polynomial regression for the eDNA reads. The fitted line for the eDNA reads have a larger standard error since these data have fewer observations. 
that the whales were being drawn nearshore by concentrated schools of anchovies. Extending the analysis of eDNA to samples collected before the start of the project, and comparing them with whale watching records and sea surface temperature data, showed a strong association between anchovies, a favored prey for whales, whale sightings, and warmer waters (Figure 12a). Further, we found a strong correlation between northern anchovy eDNA and Monterey Bay anchovy landings (Figure 12b). The record indicates an ecosystem shift from sardine and other bony fish (not shown) to anchovies. The shift is particularly interesting because previous reports showed that anchovies dominated during cooler periods (Chavez et al., 2003). Clearly, eDNA can provide important information about time-varying changes in life in the sea and will be an additional tool for understanding how marine biota respond to global environmental change. Analysis of eDNA from sediment cores has also been used to reconstruct time-varying changes in fish communities over centuries (Kuwae et al., 2020).

Another application of eDNA metabarcoding is tracking temporal changes in abundance of harmful algal bloom species. Using data from $18 \mathrm{~S}$ metabarcoding, we were able to reconstruct a time series of different Pseudo-nitzschia species in Monterey Bay at station C1 from 2008 through 2020 (Figure 13). Certain Pseudo-nitzschia species produce domoic acid, a potent neurotoxin that can cause illness and even death to wildlife (e.g., seabirds, marine mammals) and humans (who consume shellfish that have accumulated the toxin). The time-series data show seasonal and interannual variations in the timing and composition of the blooms. Pseudonitzschia australis is the most toxic of the organisms identified by metabarcoding, known to have caused serious toxic episodes in Monterey Bay during 1991, 1998, and 2015 (Buck et al., 1992; Scholin et al., 2000; Ryan et al., 2017). The 2015 episode is clearly resolved in the metabarcoding data (Figure 13). Of the two other Pseudo-nitzschia resolved to the species level, heimii is not considered toxic and fraudulenta is considered a low toxin producer (Bowers et al., 2018). The 2015 event was associated with a marine heatwave and was particularly toxic, purported to result from unusual nitrate-to-silicate ratios (Ryan et al., 2017). Metabarcoding or other molecular techniques offer a distinct advantage over traditional light microscopy in that visually differentiating species of Pseudonitzschia is problematic and in some cases impossible without the use of electron microscopy. The variability in species and toxicity shows the difficulties in predicting toxic Pseudo-nitzschia outbreaks year over year.

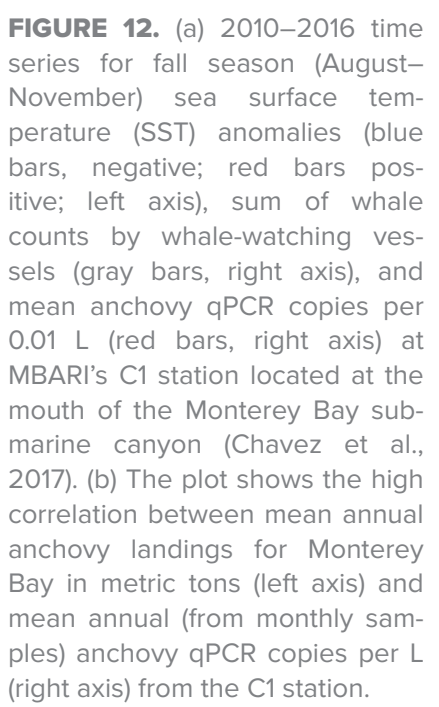

FIGURE 12. (a) 2010-2016 time series for fall season (AugustNovember) sea surface temperature (SST) anomalies (blue bars, negative; red bars positive; left axis), sum of whale counts by whale-watching vessels (gray bars, right axis), and mean anchovy qPCR copies per $0.01 \mathrm{~L}$ (red bars, right axis) at MBARl's C1 station located at the mouth of the Monterey Bay submarine canyon (Chavez et al., 2017). (b) The plot shows the high correlation between mean annual anchovy landings for Monterey Bay in metric tons (left axis) and mean annual (from monthly sam(right axis) from the $\mathrm{C} 1$ station.

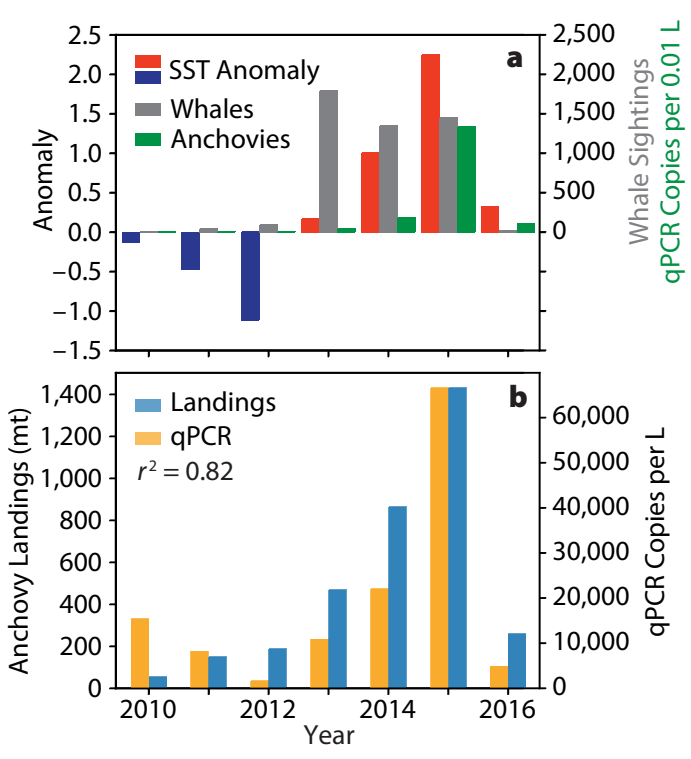

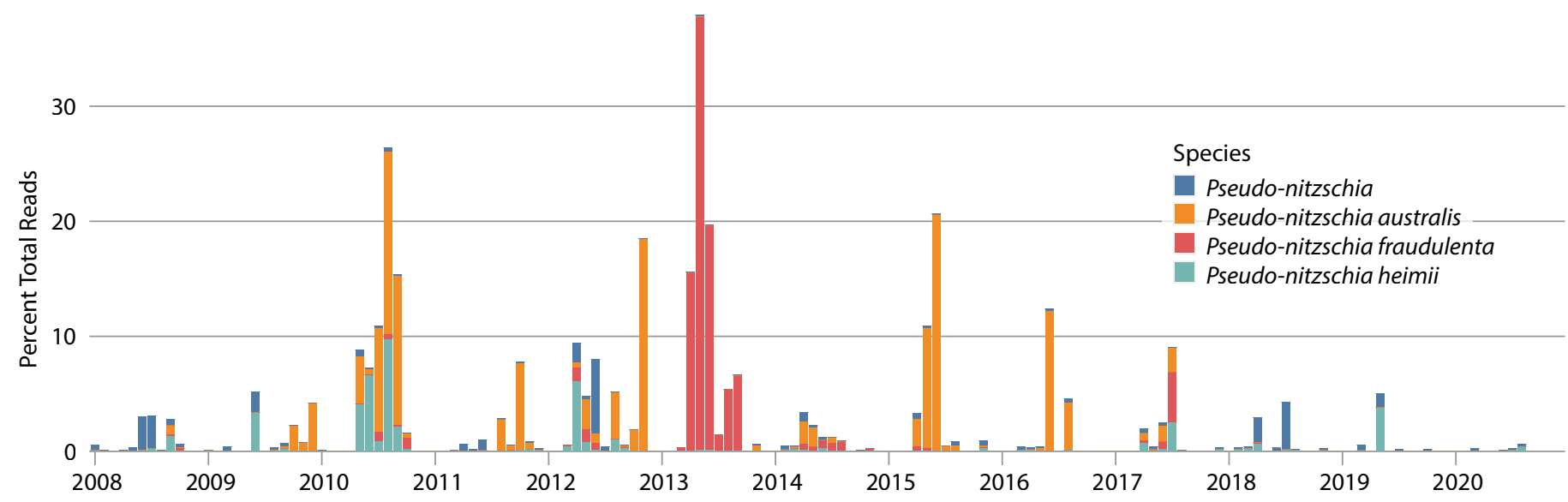

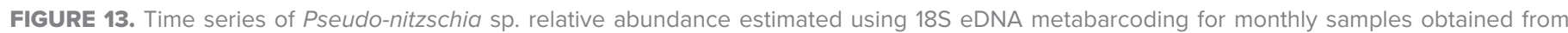

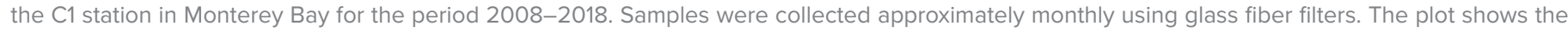

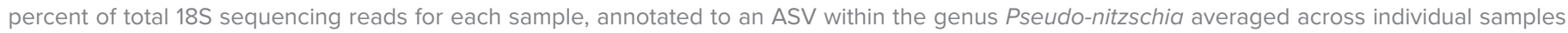
monthly. The pattern for absolute Pseudo-nitzschia sequencing reads is very similar. 


\section{THE UTILITY OF EDNA FOR SOCIETAL APPLICATIONS AND THE FUTURE}

We have introduced and reviewed the use of environmental DNA as a tool to supplement observations of life in the sea. The results from our work in and around National Marine Sanctuaries show that eDNA analysis revealed patterns similar to those seen from traditional methods (e.g., nets, microscopy, landings) and provided additional rich detail regarding ecological processes. For example, comparisons of eDNA samples across sanctuaries (from California to Florida/Gulf of Mexico) show how environmental factors (upwelling, stratification) influence community structure across ocean basins (Figure 6). Our results provide insights into the ways that eDNA can provide information on how marine communities are structured by broad geographic conditions, depth, and seasons, and how they respond to variations in climate (Figures 6-12). The advantage of eDNA is the relative ease of sample collection even though challenges still remain in processing large quantities of samples in a standardized and cost-effective manner, of eDNA data interpretation are still a matter of research, using eDNA to simply describe what species are present is relatively robust and useful for management purposes. There are still many unknowns surrounding how the genetic molecules we detect as eDNA are generated, transported, and degraded in the ocean. Furthermore, we currently treat eDNA information as qualitatively compositional, yet there are indications that (including the data shown in this paper) quantitative information can be gleaned (Yates et al., 2021), and this trend is likely to continue. Most traditional biological assessment techniques require expensive ships and utilize analytical methods that are time-consuming, including requiring visual species identifications by a dwindling community of experts. This significantly limits sampling frequency and coverage. eDNA samples, which can be taken in a more high-throughput manner from water samples, offer an incredible opportunity to increase sampling coverage and frequency through automatization (Box 2). Furthermore, unlike some traditional sample types, archival eDNA samples can be used in the future need for using metabarcoding methodologies, and (4) detection and characterization of environmental RNA of higher organisms to estimate age, health status, or responses to environmental stressors.

The transition from a technique that is currently used mostly by the research community to one that is used routinely in operational observing systems will necessarily be iterative. This will have to include streamlining collection and analysis of samples and reducing costs, as well as building tools to manage the complex documentation of methods, processing pipelines, data generated, and information products for management. An early example of eDNA management application will be the inclusion of eDNA records into National Marine Sanctuary Condition Reports, with information coming directly from repositories like the Ocean Biodiversity Information System (OBIS; see Box 1).

Within the MBON project, similar methods were employed for all samples collected, which allows for direct comparisons over space and time. Harnessing the full potential of different data sets collected across institutions and various

\section{Harnessing the full potential of different data sets collected across institutions and}

\section{various regions will be a difficult but necessary task to advance toward the goal of a truly}

global eDNA biodiversity observing system.

and in the management of resulting large and complex data sets.

Over time, the pathway for eDNA to become a routine tool for scientific, management, and conservation purposes is becoming clearer. The work of MBON and OBON is addressing the challenges required to scale biological observations spatially and temporally (see Box 2). While some aspects for interrogation regarding different taxonomic communities (Box 1). Evolution of the eDNA wheel (Figure 4) continues to advance rapidly, driven by technology developments (Box 2). Several areas that we see being particularly relevant in this regard include: (1) autonomous sample collection, (2) autonomous sample processing and sequencing in situ, (3) direct sequencing of eDNA without a regions will be a difficult but necessary task to advance toward the goal of a truly global eDNA biodiversity observing system. Together with the collection of associated environmental information and methodological metadata, once again via accepted standards, we will realize the potential to detect changes in life in the sea across environments, biomes, and over large expanses of time. This will undoubt- 
SAMPLE COLLECTION AND PROCESSING IN SITU. Autonomous sample collection is already helping to increase the temporal and spatial scales of eDNA biomonitoring. As an example, the third-generation Environmental Sample Processor (ESP; Scholin et al., 2017) is capable of collecting eDNA samples onboard crewed as well as autonomous platforms. These samples have been shown to be equivalent to those collected from CTD bottle casts (Yamahara et al., 2019). The ESP has been deployed from ships, fitted to buoys, installed on the seafloor and on a long-range autonomous underwater vehicle (LRAUV) and most recently on autonomous surface vessels. Automated sample collections provide advantages compared to collecting samples from a research vessel. For example, the ESP on an LRAUV can collect samples while continuously drifting along an ocean current and at a fixed isotherm, or on a mooring can acquire time series-both of which would be difficult and expensive to do from a ship.

SEQUENCING IN SITU. Most eDNA studies use metabarcoding primers to sequence short fragments of eDNA (i.e., $~ 100-300$ base pairs) using an Illumina MiSeq, which can sequence $\sim 20$ million short molecules of DNA (i.e., reads) per run. The newer and higher throughput Illumina NovaSeq can produce up to $\sim 20$ billion short reads per run, and this increased depth of sequencing helped improve marine eDNA methods for detecting a greater diversity of deep-sea fish species (McClenaghan et al., 2020). PacBio and Oxford Nanopore sequencers allow for sequencing of much longer fragments of eDNA than Illumina sequencers. Longread sequencing produces improved phylogenetic resolution compared to short-read sequencing, which allows for more accurate species level identifications (Krehenwinkel et al., 2017). The small size of the handheld Oxford Nanopore Minlon sequencer allows for eDNA sequencing onboard research vessels at sea (Truelove et al., 2019), and efforts are currently underway to deploy it on autonomous systems to allow for realtime eDNA sequencing in situ.
TARGETED EDNA SEQUENCING WITHOUT USING METABARCODING PRIMERS. Animal and plant eDNA tend to be present at much lower levels in seawater samples than bacterial and fungal eDNA sequences (Stat et al., 2017). Polymerase chain reaction (PCR) using metabarcoding primers are often used in marine eDNA research to boost the signals of plant and animal species when sequencing seawater samples. PCR bias, however, can skew the relative abundance of species detected (van der Loos and Nijland, 2021) by preferentially amplifying some species while failing to detect others (McClenaghan et al., 2020). Targeted capture sequencing is an alternative PCR-free approach for boosting the signal of animal and plant species found in marine eDNA. Target capture probes can be developed to specifically bind animal and plant eDNA sequences of interest to magnetic beads, then all other eDNA sequences present in the environmental sample are washed away. The captured eDNA sequences of interest are then directly sequenced. This approach provided more accurate relative abundance data (Wilcox et al., 2018), assembled complete mitochondrial genomes, and identified thousands of nuclear markers that can be used for population genetics from seawater eDNA samples (Jensen et al., 2021).

\section{ENVIRONMENTAL RNA FOR DETECTING THE LIFE HISTORY STAGES} AND THE HEALTH OF SPECIES. The relatively new field of environmental RNA (eRNA) for higher organisms has the potential to provide high resolution ecological data from seawater samples relevant to age, size, and sex, as well as providing insight into the overall health of marine species and populations (Yates et al., 2021). While eDNA provides an understanding of the genetic makeup of species present in a seawater sample, eRNA provides specific knowledge of the types of genes that are actively being expressed in an environmental sample. Marine species show substantially different levels of gene expression depending on their life-history stage, sex, and exposure to environmental stressors such as elevated temperature, hypoxia, and pollution (Yates et al., 2021). Combining gene expression data obtained from eRNA with species assemblage data from eDNA will greatly increase the amount of ecological information that can be gleaned from marine environmental samples (von Ammon et al., 2019).

\section{THE FUTURE: eDNA SEQUENCING AND BIOINFORMATICS IN SITU AT SEA}

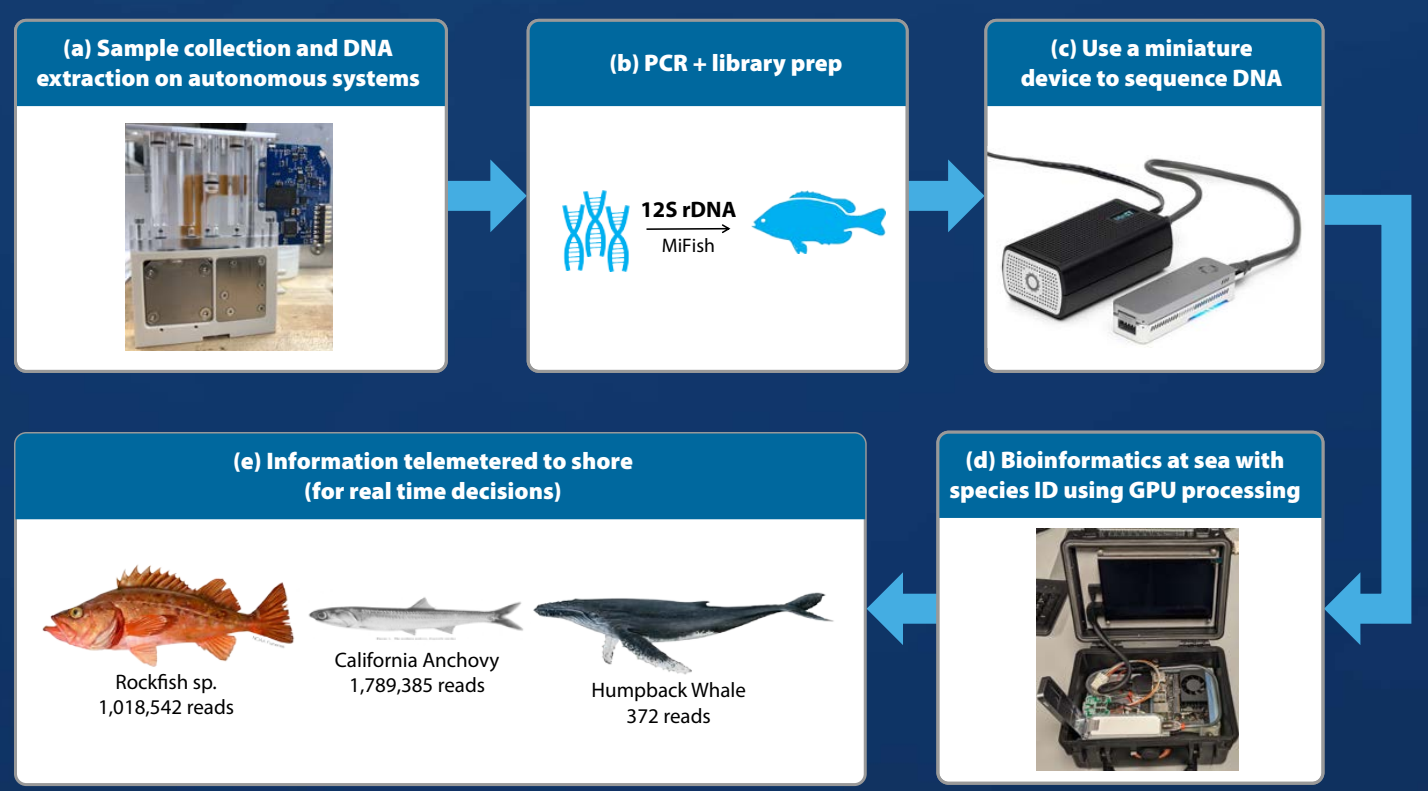

FICURE B2-1. In a not-toodistant future, performance of the relatively complex series of eDNA processing procedures that are currently conducted mostly by humans will be fully automated. Collection and extraction aboard autonomous systems is already possible (Scholin et al., 2017). The remaining steps are being tested in the field onboard research vessels but eventually will be done in situ. This automation will scale the collection of information about life in the sea closer to what is currently being done for ocean physics and biogeochemistry. 
edly play a key role in understanding the extent and trajectory of change, driven by growing worldwide changes in climate and other anthropogenic stressors (e.g., overfishing, warming, ocean acidification, pollution; Figure 14).

In summary, this is an exciting time for research involving marine environmental DNA and other biomolecular methods, a field that is at the forefront of scientific research, technology development, resource management, and conservation (Goodwin et al., 2017). As with any emerging field, there are many opportunities and challenges (Table 2). The opportunities include: (1) the potential to survey the full marine food web, from microbes to whales, from a single water sample; (2) surveying commercially important groups at reduced costs and increased resolution; (3) improved and early detection of endangered, invasive, harmful, and pathogenic species; (4) the development of new techniques that may be more quantitative and can provide information regarding age and health of populations; (5) the potential to scale observations globally by automating sample collection, laboratory processing, sequencing, bioinformatics, and telemetry; and (6) expanding sequence reference data bases, including expert taxonomic characterization and species vouchering. The challenges include: (1) a rapidly evolving field where methods and techniques are constantly changing and improving, complicating site to site and time series comparisons; (2) integrating eDNA into resource management practices; (3) agreeing on standards for regional, national, and international programs; (4) managing the data

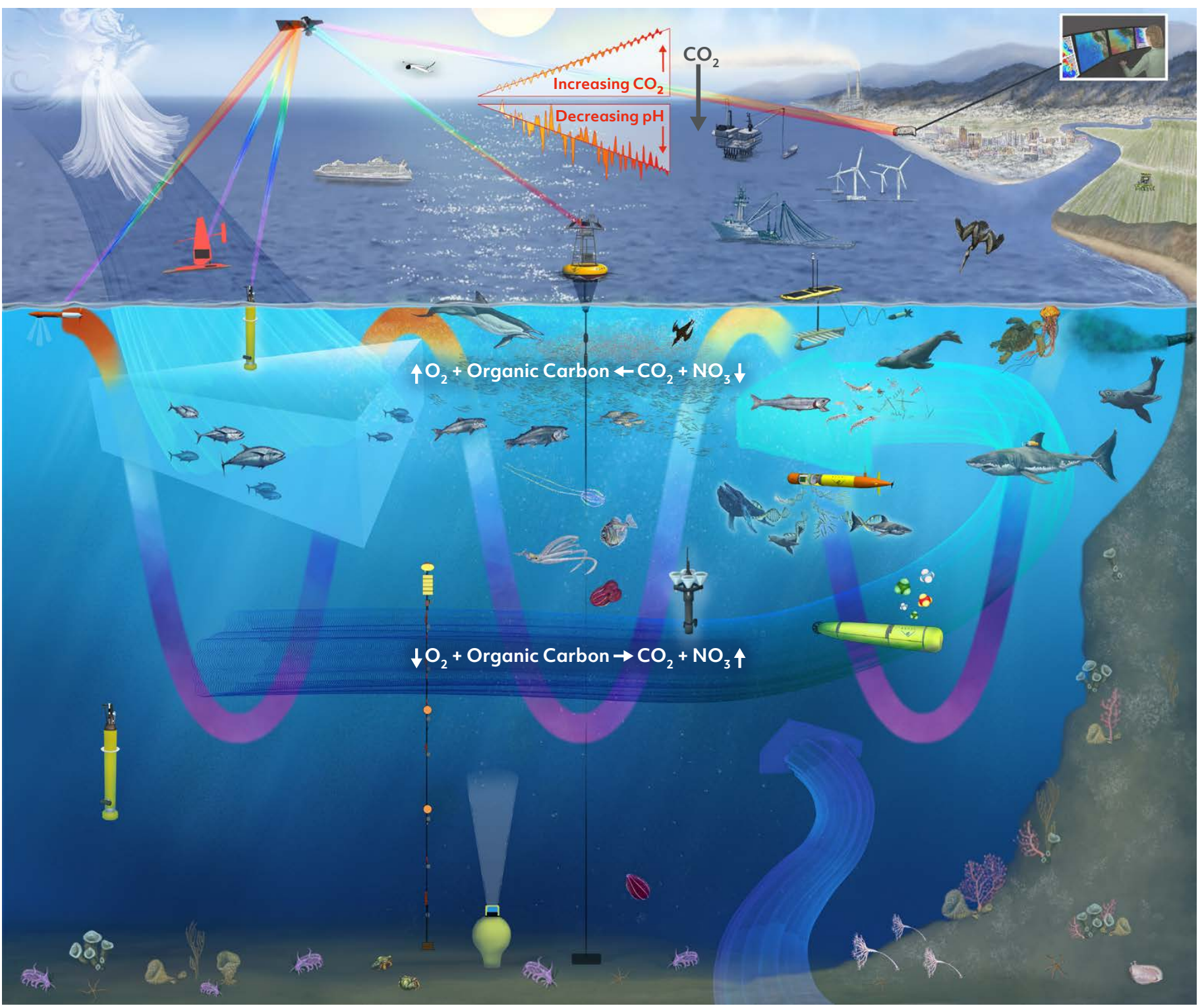

FIGURE 14. Environmental DNA is rapidly becoming an important tool for observing life in the sea within an ever-changing world. Local changes

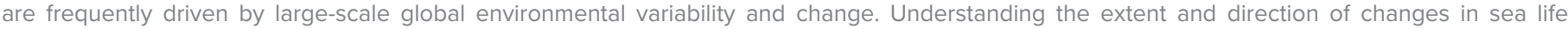

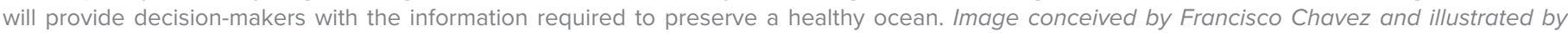
Kelly Lance (c) MBARI 
The "complete" ocean food web at increased resolution

A rapidly evolving scientific and technology seascape

Survey commercially and socially relevant species at reduced costs

Moving beyond basic research-is it quantitative and scalable?

Detection of endangered, invasive, harmful and pathogenic species

Standards-from methods to analysis, multiple options and evolving techniques

New techniques that are more quantitative and can provide information about a population's age and health

Managing big data and associated metadata

Scalable to full "automation" and with routine global coverage

Expanding sequence reference data bases including expert taxonomic characterization and species vouchering

Integration of disciplines-omics, ecology and oceanography, acoustics, optics, engineering, marine operations

Modeling-moving from NPZ (Nutrients, Phytoplankton, Zooplankton) to NACGT (Nutrients, adenine [A], cytosine [C], guanine [G], thymine [T])

and associated metadata-the scale of this effort has not yet been fully appreciated and the community should look at other fields with more experience (i.e., remote sensing) for lessons learned; (5) development of a new generation of scientists trained to integrate genetic information with other biological sensing methods, ecology, and oceanography; and (6) incorporating genetic information into numerical (ecosystem) models. The coming decade that coincides with the United Nations Ocean Decade for Sustainable Development should see great advances on many of these fronts. [C

\section{MATERIALS AND METHODS}

eDNA samples in this analysis were drawn from seawater collected from shipboard CTD rosettes, from autonomous vehicles, and by scuba divers. These water samples were then filtered through a peristaltic pump system, vacuum pump system, or autonomously through an Environmental Sample Processo instrument (Scholin et al., 2017). Filters ranged from $0.2 \mu \mathrm{m}$ PVDF membranes to glass fiber filters (GFF). DNA was extracted following the protocols found at https://doi.org/10.17504/protocols.io.n2udgew, then PCR amplified (18S: https://doi.org/10.17504/ protocols.io.n2vdge6; COI: https://doi.org/10.17504/ protocols.io.mwnc7de; 12S: https://doi.org/10.17504/ protocols.io.bcppivmn), and sequenced. As eDNA methods are rapidly evolving, wet lab procedures used within this project have shifted as well, resulting in both advances as well as interoperability challenges. Sequencing results were processed bioinformatically through a custom shell script adapted from the banzai pipeline and run on a per-plate basis (O'Donnell et al., 2016, https://github.com/MBARIBOG/BOG-Banzai-Dada2-Pipeline). Within the script, primer sequences are first removed from fastq files through the program Atropos (Didion et al., 2017). Fastq files are then fed into the Dada2 program (Camacho et al., 2009; Callahan et al., 2016). Dada2 models DNA sequencing error on a per-Illumina run basis, controlling for read quality and picking ASV sequences that represent biological variability rather than sequencing error (Callahan et al., 2016). Within Dada2, reads are trimmed to remove low-quality regions and filtered by quality score, sequencing errors are modeled and removed, and reads are then merged and chimeric sequences removed. Taxonomy is assigned to the resulting ASV sequences through blastn searches to NCBI GenBank's non-redundant nucleotide database (nt) (D.A. Benson et al., 2013). Blast results are filtered using MEGAN6's lowest common ancestor (LCA) algorithm (Huson et al., 2016). Only hits with $\geq 80 \%$ sequence identity and whose bitscores were within the top $2 \%$ of the highest bitscore value for each OTU are considered by MEGAN6. The MEGAN6 parameter LCA percent is set to 0.8 , allowing for up to $20 \%$ of top hits to be off target and still have the majority taxonomy assigned. This parameter value was chosen to allow for minor numbers of incorrectly annotated GenBank entries-effectively allowing for ASVs that had many high-quality hits to a taxa to still be assigned to that taxa even if there was a high-bitscore hit to another GenBank sequence annotated to an unrelated taxa. Post-MEGAN6 filtering is performed to ensure only contigs with a hit of $\geq 97 \%$ sequence identity is annotated to the species level. Only contigs with a hit of $\geq 95 \%$ sequence identity is annotated to the genus level. Annotations are elevated to the next highest taxonomic level for contigs that fail these conditions.

\section{REFERENCES}

Amaral-Zettler, L.A., E.A. McCliment, H.W. Ducklow, and S.M. Huse. 2009. A method for studying protistan diversity using massively parallel sequencing of V9 hypervariable regions of small-subunit ribosomal RNA genes. PLOS ONE 4(7):1-9, https://doi.org/10.1371/journal.pone.0006372.

Andersson, A.F., A. Bissett, A.G. Finstad,

F. Fossøy, M. Grosjean, M. Hope, T.S. Jeppesen, U. Kõljalg, D. Lundin, R.N. Nilsson, and others. 2020. Publishing DNA-derived Data Through Biodiversity Data Platforms, v1.0. GBIF Secretariat, Copenhagen, 50 pp.

Arnosti, C., K.-U. Hinrichs, S. Coffinet, H. Wilkes, and S. Pantoja. 2019. The enduring questions: What's for dinner? Where's my knife? ... And can I use my fingers? (Unanswered) questions related to organic matter and microbes in marine sediments. Frontiers in Marine Science 6:629, https://doi.org/10.3389/ fmars.2019.00629.

Benson, A., T. Murray, G. Canonico, E. Montes, F.E. Muller-Karger, M.T. Kavanaugh, J. Triñanes, and L.M. deWitt. 2021. Data management and interactive visualizations for the evolving Marine Biodiversity Observation Network. Oceanography 34(2):130-141, https://doi.org/ 10.5670/oceanog.2021.220.

Benson, D.A., M. Cavanaugh, K. Clark, I. KarschMizrachi, D.J. Lipman, J. Ostell, and E.W. Sayers. 2013. GenBank. Nucleic Acids Research 41 (Database issue):D36-D42, https://doi.org/10.1093/ nar/gks1195.

Bohmann, K., A. Evans, M.T.P. Gilbert, G.R. Carvalho, S. Creer, M. Knapp, D.W. Yu, and M. de Bruyn. 2014. Environmental DNA for wildlife biology and biodiversity monitoring. Trends in Ecology \& Evolution 29(6):358-367, https://doi.org/10.1016/ j.tree.2014.04.003.

Bond, N.A., M.F. Cronin, H. Freeland, and N. Mantua. 2015. Causes and impacts of the 2014 warm anomaly in the NE Pacific. Geophysical Research Letters 42(9):3,414-3,420, https://doi.org/10.1002/ 2015 GL063306.

Bowers, H.A., J.P. Ryan, K. Hayashi, A.L. Woods, R. Marin III, G.J. Smith, K.A. Hubbard, G.J. Doucette, C.M. Mikulski, A.G. Gellene, and others. 2018. Diversity and toxicity of Pseudo-nitzschia species in Monterey Bay: Perspectives from targeted and adaptive sampling. Harmful Algae 78:129-141, https://doi.org/10.1016/j.hal.2018.08.006.

Bray, J.R., and J.T. Curtis. 1957. An ordination of the upland forest communities of southern Wisconsin. Ecological Monographs 27(4):325-349, https://doi.org/10.2307/1942268.

Buck, K.R., L. Uttal-Cooke, C.H. Pilskaln, D.L. Roelke, M.C. Villac, G.A. Fryxell, L. Cifuentes, and F.P. Chavez. 1992. Autoecology of Pseudonitzschia australis, a domoic acid producer, from Monterey Bay, California. Marine Ecology Progress Series 84:293-302, https://doi.org/10.3354/ meps084293.

Buttigieg, P.L., and A. Ramette. 2015. Biogeographic patterns of bacterial microdiversity in Arctic deepsea sediments (HAUSGARTEN, Fram Strait). Frontiers in Microbiology 5:660, https://doi.org/ 10.3389/fmicb.2014.00660.

Callahan, B.J., P.J. McMurdie, M.J. Rosen, A.W. Han, A.J.A. Johnson, and S.P. Holmes. 2016. DADA2: High-resolution sample inference from Illumina amplicon data. Nature Methods 13(7):581-583, https://doi.org/10.1038/nmeth.3869.

Camacho, C., G. Coulouris, V. Avagyan, N. Ma, J. Papadopoulos, K. Bealer, and T.L. Madden. 2009. BLAST+: Architecture and applications. BMC Bioinformatics 10(1):421, https://doi.org/ 10.1186/1471-2105-10-421. 
Chavez, F.P., J. Ryan, S.E. Lluch-Cota, and M. Ñiquen C. 2003. From anchovies to sardines and back: Multidecadal change in the Pacific Ocean. Science 299(5604):217-221, https://doi.org/10.1126/ science.1075880

Chavez, F.P., J.T. Pennington, R.P. Michisaki, M. Blum, G.M. Chavez, J. Friederich, B. Jones, R. Herlien, B. Kieft, B. Hobson, and others. 2017. Climate variability and change: Response of a coastal ocean ecosystem. Oceanography 30(4):128-145, https://doi.org/10.5670/oceanog.2017.429.

Chavez, F., and K. Pitz. 2021. 18S Monterey Bay Time Series: An eDNA data set from Monterey Bay, California, including years 2006, 2013-2016. [Dataset] Available: Ocean Biodiversity Information System. Intergovernmental Oceanographic Commission of UNESCO, https://www.obis.org/.

Chavez, F., K. Pitz, and D. LaScala-Gruenewald. 2021. 18S Monterey Bay Time Series: An eDNA data set from Monterey Bay, California, including years 2006, 2013-2016. United States Geological Survey. Occurrence data set, https://doi.org/ 10.15468/84ntea.

Clarke, G.L., G.C. Ewing, and C.J. Lorenzen. 1970. Spectra of backscattered light from the sea obtained from aircraft as a measure of chlorophyll concentration. Science 167(3921):1,119-1,121, https://doi.org/10.1126/science.167.3921.1119.

Closek, C.J., J.A. Santora, H.A. Starks, I.D. Schroeder, E.A. Andruszkiewicz, K.M. Sakuma, S.J. Bograd, E.L. Hazen, J.C. Field, and A.B. Boehm. 2019. Marine vertebrate biodiversity and distribution within the Central California Current using environmental DNA (eDNA) metabarcoding and ecosystem surveys. Frontiers in Marine Science 6:732, https://doi.org/10.3389/fmars.2019.00732.

Cristescu, M.E., and P.D.N. Hebert. 2018. Uses and misuses of environmental DNA in biodiversity science and conservation. Annual Review of Ecology, Evolution, and Systematics 49:209-230, https://doi.org/10.1146/ annurev-ecolsys-110617-062306.

Darling, J.A. 2020. How to learn to stop worrying and love environmental DNA monitoring. Aquatic Ecosystem Health \& Management 22(4):440-451, https://doi.org/10.1080/14634988.2019.1682912.

Deiner, K., H.M. Bik, E. Mächler, M. Seymour, A. Lacoursière-Roussel, F. Altermatt, S. Creer, I. Bista, D.M. Lodge, N. de Vere, and others. 2017. Environmental DNA metabarcoding: Transforming how we survey animal and plant communities. Molecular Ecology 26(21):5,872-5,895, https://doi.org/10.1111/mec.14350.

Didion, J.P., M. Martin, and F.S. Collins. 2017 Atropos: Specific, sensitive, and speedy trimming of sequencing reads. PeerJ 2017(8):e3720, https://doi.org/10.7717/peerj.3720.

Djurhuus, A., C.J. Closek, R.P. Kelly, K.J. Pitz, R.P. Michisaki, H.A. Starks, K.R. Walz, E.A. Nndruszkiewicz, E. Olesin, K. Hubbard, and others. 2020. Environmental DNA reveals seasonal shifts and potential interactions in a marine community. Nature Communications 11(1):254, https://doi.org/10.1038/s41467-019-14105-1.

Espinoza, P., and A. Bertrand. 2008. Revisiting Peruvian anchovy (Engraulis ringens) trophodynamics provides a new vision of the Humboldt Current System. Progress in Oceanography 79(2):215-227, https://doi.org/10.1016/j. pocean.2008.10.022.

Folmer, O., M. Black, W. Hoeh, R. Lutz, and R. Vrijenhoek. 1994. DNA primers for amplification of mitochondrial cytochrome c oxidase subunit I from diverse metazoan invertebrates. Molecular Marine Biology and Biotechnology 3(5):294-99.
Goodwin, K.D., L.R. Thompson, B. Duarte, T. Kahlke, A.R. Thompson, J.C. Marques, and I. Caçador. 2017. DNA sequencing as a tool to monitor marine ecological status. Frontiers in Marine Science 4:107, https://doi.org/10.3389/fmars.2017.00107.

Huson, D.H., S. Beier, I. Flade, A. Górska, M. El-Hadidi, S. Mitra, H.J. Ruscheweyh, and R. Tappu. 2016. MEGAN community edition-Interactive exploration and analysis of large-scale microbiome sequencing data. PLoS Computational Biology 12(6):e1004957, https://doi.org/10.1371/journal.pcbi.1004957.

Jackson, G.A., and D.M. Checkley Jr. 2011. Particle size distributions in the upper $100 \mathrm{~m}$ water column and their implications for animal feeding in the plankton. Deep Sea Research Part / 58(3):283-297, https://doi.org/10.1016/j.dsr.2010.12.008.

Jensen, M.R., E.E. Sigsgaard, S. Liu, A. Manica, S.S. Bach, M.M. Hansen, P.R. Møller, and P.F. Thomsen. 2021. Genome-scale target capture of mitochondrial and nuclear environmental DNA from water samples. Molecular Ecology Resources 21(3):690-702, https://doi.org/10.1111/ 1755-0998.13293.

Kelly, R.P., J.A. Port, K.M. Yamahara, and L.B. Crowder. 2014. Using environmental DNA to census marine fishes in a large mesocosm. PLoS One 9(1):e86175, https://doi.org/10.1371/journal.pone.0086175.

Krehenwinkel, H., M. Wolf, J.Y. Lim, A.J. Rominger, W.B. Simison, and R.G. Gillespie. 2017. Estimating and mitigating amplification bias in qualitative and quantitative arthropod metabarcoding. Scientific Reports 7:17668, https://doi.org/10.1038/ s41598-017-17333- $x$

Kuwae, M., H. Tamai, H. Doi, M.K. Sakata, T. Minamoto, and Y. Suzuki. 2020. Sedimentary DNA tracks decadal-centennial changes in fish abundance. Communications Biology 3(1):558, https://doi.org/ 10.1038/s42003-020-01282-9.

Lamy, T., K.J. Pitz, F.P. Chavez, C.E. Yorke, and R.J. Miller. 2021. Environmental DNA reveals the fine-grained and hierarchical spatial structure of kelp forest fish communities. Scientific Reports 2021 11:14439, https://doi.org/10.1038/ s41598-021-93859-5.

Leray, M., J.Y. Yang, C.P. Meyer, S.C. Mills, N. Agudelo, V. Ranwez, J.T. Boehm, and R.J. Machida. 2013. A new versatile primer set targeting a short fragment of the mitochondrial $\mathrm{COI}$ region for metabarcoding metazoan diversity: Application for characterizing coral reef fish gut contents. Frontiers in Zoology 10:34, https://doi.org/10.1186/ 1742-9994-10-34.

Margalef, R. 1978. Life-forms of phytoplankton as survival alternatives in an unstable environment. Oceanologica Acta 1(4):493-509.

Martino, C., J.T. Morton, C.A. Marotz, L.R. Thompson, A. Tripathi, R. Knight, and K. Zengler. 2019. A novel sparse compositional technique reveals microbial perturbations. MSystems 4(1), https://doi.org/ 10.1128/mSystems.00016-19.

McClenaghan, B., Z.G. Compson, and M. Hajibabaei. 2020. Validating metabarcoding-based biodiversity assessments with multi-species occupancy models: A case study using coastal marine eDNA. PLoS ONE 15(3):e0224119, https://doi.org/10.1371/ journal.pone.0224119.

Messié, M., and F.P. Chavez. 2017. Nutrient supply, surface currents, and plankton dynamics predict zooplankton hotspots in coastal upwelling systems. Geophysical Research Letters 44(17):8,979-8,986, https://doi.org/10.1002/2017GL074322.

Miya, M., Y. Sato, T. Fukunaga, T. Sado, J.Y. Poulsen, K. Sato, T. Minamoto, S. Yamamoto, H. Yamanaka, H. Araki, M. Kondoh, and W. Iwasaki. 2015. MiFish, a set of universal PCR primers for metabarcoding environmental DNA from fishes: Detection of more than 230 subtropical marine species. Royal Society Open Science 2(7):150088, https://doi.org/10.1098/ rsos.150088.
O'Donnell, J.L., R.P. Kelly, N.C. Lowell, and J.A. Port. 2016. Indexed PCR primers induce templatespecific bias in large-scale DNA sequencing studies. PLoS ONE 11(3):e0148698, https://doi.org/ 10.1371/journal.pone.0148698.

Oksanen, J., F.G. Blanchet, M. Friendly, R. Kindt, P. Legendre, D. McGlinn, P.R. Minchin, R.B. O'Hara, G.L. Simpson, P. Solymos, and others. 2019. Vegan: Community ecology package, https://cran.r-project. org/package=vegan.

Parada, A.E., D.M. Needham, and J.A. Fuhrman. 2016. Every base matters: Assessing small subunit RRNA primers for marine microbiomes with mock communities: Time series and global field samples. Environmental Microbiology 18(5):1,403-1,414, https://doi.org/10.1111/1462-2920.13023.

Pawlowski, J., L. Apothéloz-Perret-Gentil, and F. Altermatt. 2020. Environmental DNA: What's behind the term? Clarifying the terminology and recommendations for its future use in biomonitoring. Molecular Ecology 29(22):4,258-4,264, https://doi.org/10.1111/mec.15643.

Peterson, W.T., and J.E. Keister. 2003. Interannual variability in copepod community composition at a coastal station in the Northern California Current: A multivariate approach. Deep Sea Research Part // 50(14-16):2,499-2,517, https://doi.org/ 10.1016/S0967-0645(03)00130-9.

Pitz, K.J., J. Guo, S.B. Johnson, T.L. Campbell, H. Zhang, R.C. Vrijenhoek, F.P. Chavez, and J. Geller. 2020. Zooplankton biogeographic boundaries in the California Current System as determined from metabarcoding. PLoS ONE 15(6):e0235159, https://doi.org/10.1371/ journal.pone.0235159.

Port, J.A., J.L. O'Donnell, O.C. Romero-Maraccini, P.R. Leary, S.Y. Litvin, K.J. Nickols, K.M. Yamahara, and R.P. Kelly. 2016. Assessing vertebrate biodiversity in a kelp forest ecosystem using environmental DNA. Molecular Ecology 25(2):527-541, https://doi.org/10.1111/mec.13481.

Quince, C., A. Lanzen, R.J. Davenport, and P.J. Turnbaugh. 2011. Removing noise from pyrosequenced amplicons. BMC Bioinformatics 12:38, https://doi.org/10.1186/1471-2105-12-38.

Rodriguez-Ezpeleta, N., O. Morissette, C.W. Bean, S. Manu, P. Banerjee, A. Lacoursière-Roussel, K.C. Beng, S.E. Alter, F. Roger, L.E. Holman, and others. 2021. Trade-offs between reducing complex terminology and producing accurate interpretations from environmental DNA: Comment on 'Environmental DNA: What's behind the term?' by Pawlowski et al., (2020). Molecular Ecology 30(19):4,601-4,605, https://doi.org/10.1111/ mec.15942.

Ryan, J.P., R.M. Kudela, J.M. Birch, M. Blum, H.A. Bowers, F.P. Chavez, G.J. Doucette, K. Hayashi, R. Marin III, C M. Mikulski, and others. 2017. Causality of an extreme harmful algal bloom in Monterey Bay, California, during the 2014-2016 northeast Pacific warm anomaly. Geophysical Research Letters 44(11):5,571-5,579, https://doi.org/ 10.1002/2017GL072637.

Ryther, J.H. 1969. Photosynthesis and fish production in the sea. Science 166(3901):72-76, https://doi.org/ 10.1126/science.166.3901.72.

Samuel, R.M., R. Meyer, P.L. Buttigieg, N. Davies, N.W. Jeffery, C. Meyer, C. Pavloudi, K.J. Pitz, M. Sweetlove, S. Theroux, and others. 2021. Toward a global public repository of community protocols to encourage best practices in biomolecular ocean observing and research. Frontiers in Marine Science 8:758694, https://doi.org/10.3389/ fmars.2021.758694.

Santora, J.A., N.J. Mantua, I.D. Schroeder, J.C. Field, E.L. Hazen, S.J. Bograd, W.J. Sydeman, B.K. Wells, J. Calambokidis, L. Saez, and others. 2020. Habitat compression and ecosystem shifts as potential 
links between marine heatwave and record whale entanglements. Nature Communications 11:536, https://doi.org/10.1038/s41467-019-14215-w.

Scholin, C.A., F. Gulland, G.J. Doucette, S. Benson, M. Busman, F.P. Chavez, J. Cordaro, R. DeLong, A. De Vogelaere, J. Harvey, and others. 2000. Mortality of sea lions along the central California coast linked to a toxic diatom bloom. Nature 403:80-84, https://doi.org/10.1038/47481.

Scholin, C.A., J. Birch, S. Jensen, R. Marin III, E. Massion, D. Pargett, C. Preston, B. Roman, and W. Ussler III. 2017. The quest to develop ecogenomic sensors: A 25-year history of the Environmental Sample Processor (ESP) as a case study. Oceanography 30(4):100-113, https://doi.org/ 10.5670/oceanog.2017.427.

Stat, M., M.J. Huggett, R. Bernasconi, J.D. Dibattista, T.E. Berry, S.J. Newman, E.S. Harvey, and M. Bunce. 2017. Ecosystem biomonitoring with eDNA: Metabarcoding across the tree of life in a tropical marine environment. Scientific Reports 7:12240, https://doi.org/10.1038/s41598-017-12501-5.

Suzuki, K., Y. Nakamura, and J. Hiromi. 1999. Feeding by the small calanoid copepod Paracalanus sp. on heterotrophic dinoflagellates and ciliates. Aquatic Microbial Ecology: International Journal 17:99-103, https://doi.org/10.3354/ame017099.

Taberlet, P., E. Coissac, M. Hajibabaei, and L.H. Rieseberg. 2012. Environmental DNA Molecular Ecology 21(8):1,789-1,793, https://doi.org/ 10.1111/j.1365-294X.2012.05542.x.

Thomsen, P.F., J. Kielgast, L.L. Iversen, P.R. Møller, M. Rasmussen, and E. Willerslev. 2012. Detection of a diverse marine fish fauna using environmental DNA from seawater samples. PLoS ONE 7(8):e41732, https://doi.org/10.1371/ journal.pone.0041732.

Thomsen, P.F., and E. Willerslev. 2015. Environmental DNA-An emerging tool in conservation for monitoring past and present biodiversity. Biological Conservation 183:4-18, https://doi.org/10.1016/ j.biocon.2014.11.019.

Truelove, N.K., E.A. Andruszkiewicz, and B.A. Block. 2019. A rapid environmental DNA method for detecting white sharks in the open ocean. Methods in Ecology and Evolution 10(8):1,128-1,135, https://doi.org/10.1111/2041-210X.13201.

van der Loos, L.M., and R. Nijland. 2021. Biases in bulk: DNA metabarcoding of marine communities and the methodology involved. Molecular Ecology 30(13):3,270-3,288, https://doi.org/10.1111/ mec.15592.

von Ammon, U., S.A. Wood, O. Laroche, A. Zaiko, S.D. Lavery, G.J. Inglis, and X. Pochon. 2019. Linking environmental DNA and RNA for improved detection of the marine invasive fanworm Sabella spallanzanii. Frontiers in Marine Science 6:621, https://doi.org/10.3389/fmars.2019.00621.

West, K., M.J. Travers, M. Stat, E.S. Harvey, Z.T. Richards, J.D. DiBattista, S.J. Newman, A. Harry, C.L. Skepper, M. Heydenrych, and M. Bunce. 2021 Large-scale eDNA metabarcoding survey reveals marine biogeographic break and transitions over tropical North-Western Australia. Diversity and Distributions 27(10):1,942-1,957, https://doi.org/ 10.1111/ddi.13228.

Wieczorek, J., D. Bloom, R. Guralnick, S. Blum, M. Döring, R. Giovanni, T. Robertson, and D. Vieglais. 2012. Darwin Core: An evolving community-developed biodiversity data standard. PLoS ONE 7(1):e29715, https://doi.org/10.1371/ journal.pone.0029715.

Wilcox, T.M., K.E. Zarn, M.P. Piggott, M.K. Young, K.S. McKelvey, and M.K. Schwartz. 2018. Capture enrichment of aquatic environmental DNA: A first proof of concept. Molecular Ecology Resources 18(6):1,392-1,401, https://doi.org/ 10.1111/1755-0998.12928.
Yamahara, K.M., C.M. Preston, J. Birch, K. Walz,

R. Marin, S. Jensen, D. Pargett, B. Roman,

W. Ussler III, Y. Zhang, and others. 2019. In situ autonomous acquisition and preservation of marine environmental DNA using an autonomous underwater vehicle. Frontiers in Marine Science 6:373, https://doi.org/10.3389/fmars.2019.00373.

Yates, M.C., D.M. Glaser, J.R. Post, M.E. Cristescu, D.J. Fraser, and A.M. Derry. 2021. The relationship between eDNA particle concentration and organism abundance in nature is strengthened by allometric scaling. Molecular Ecology 30(13):3,068-3,082, https://doi.org/10.1111/ mec.15543.

Zaiko, A., P. Greenfield, C. Abbott, U. von Ammon, J. Bilewitch, M. Bunce, M.E. Cristescu, A. Chariton, E. Dowle, J. Geller, and others. 2021. Towards reproducible metabarcoding data: Lessons from an international cross-laboratory experiment. Molecular Ecology Resources, https://doi.org/ 10.1111/1755-0998.13485.

\section{ACKNOWLEDGMENTS}

This effort was funded by NASA awards NNX14AP62A, 80NSSCC20M001, and $80 N S S C 21 M 0032$, NOAA award NA16NOS0120021, and by the David and Lucile Packard Foundation.

\section{AUTHORS}

Francisco P. Chavez (chfr@mbari.org) is Senior Scientist, Monterey Bay Aquarium Research Institute (MBARI), Moss Landing, CA, USA. Markus Min is a graduate student in the School of Aquatic and Fishery Sciences, University of Washington, Seattle, WA, USA. Kathleen Pitz is Senior Research Technician, Nathan Truelove is Senior Research Technician, Jacoby Baker is Research Assistant, Diana LaScala-Grunewald is Data Scientist, Marguerite Blum is Research Technician, and Kristine Walz is Senior Research Technician, all at MBARI, Moss Landing, CA, USA. Charles Nye is Marine Mammal Institute Graduate Fellow, Oregon State University, Corvallis, OR, USA. Anni Djurhuus is Assistant Professor, University of the Faroe Islands, Tórshavn, Faroe Islands, Denmark. Robert J. Miller is Research Biologist, Marine Science Institute, University of California, Santa Barbara, CA, USA. Kelly D. Goodwin is Researcher, Ocean Chemistry and Ecosystems Division, Atlantic Oceanographic and Meteorological Laboratory, National Oceanic and Atmospheric Administration, Miami, FL, USA. Frank E. Muller-Karger is Professor, College of Marine Science, University of South Florida, St. Petersburg, FL, USA. Henry A. Ruhl is CeNCOOS Director, and Christopher A. Scholin is President and CEO, MBARI, Moss Landing, CA, USA.

\section{ARTICLE CITATION}

Chavez, F.P., M. Min, K. Pitz, N. Truelove,

J. Baker, D. LaScala-Grunewald, M. Blum, K. Walz,

C. Nye, A. Djurhuus, R.J. Miller, K.D. Goodwin F.E. Muller-Karger, H.A. Ruhl, and C.A. Scholin. 2021. Observing life in the sea using environmental DNA. Oceanography 34(2):102-119, https://doi.org/10.5670/ oceanog.2021.218.

\section{COPYRIGHT \& USAGE}

This is an open access article made available under the terms of the Creative Commons Attribution 4.0 International License (https://creativecommons.org/ licenses/by/4.0/), which permits use, sharing, adaptation, distribution, and reproduction in any medium or format as long as users cite the materials appropriately, provide a link to the Creative Commons license, and indicate the changes that were made to the original content. 